\title{
LAS COOPERATIVAS DE RIEGO COMO INSTRUMENTOS PARTICULARES DE APROPIACION ELITISTA DE TIERRAS EN EL VALLE DEL RIO NEGRO
}

\section{INTRODUCCIÓN}

Durante los primeros años de este siglo y al amparo de un decreto del gobierno argentino del 27 de septiembre de 1907 se crearon, en los valles Superior y Medio del Río Negro, entidades societarias cuyo objetivo declarado consistía en dotar a dichas zonas de canales de riego imprescindibles para la producción agrícola. Se trató de las denominadas: Sociedad Cooperativa de Irrigación Limitada de la Colonia General Roca (1907); Sociedad Cooperativa de Irrigación de Choele Choel (1908); Sociedad Cooperativa Limitada de Irrigación Colonia Cervantes (1910), y Sociedad Cooperativa del Este (1911).

El punto de vista que aporta la bibliografía existente — desde los hoy ya clásicos trabajos de Molins o Mailhet hasta la producción más reciente de los historiadores - coincide en destacar el papel progresista y modernizador que, supuestamente, habrían jugado tales entidades en el desarrollo económico de la región en consonancia con sus propósitos manifiestos.

Mientras Molins afirma que con el decreto del 27 de septiembre de 1907 se iniciaba «el verdadero ciclo agrícola de la zona», Maillet opina que «esa época marca la etapa progresista de la Colonia Roca». Toledo, por su parte, ve en esas entidades la corporización de los principios enunciados en 1884 por los pioneros ingleses de Rochdale para terminar afirmando, enfáticamente, que «es todo un orgullo para la que llegaría a ser una de las más im. portantes zonas agrícolas del país, que su primitivo riego se haya

Tomo XLVII 
orientado por el método cooperativo». 'Otros llegan aún más lejos. Tal es el caso de Maida, cuando asevera:

"El texto del decreto refleja la preocupación del gobierno por lacilitar al pequeño y mediano agricultor el acceso a la tierra. Atento a las características de suelo y clima que suponen factores nega. tivos al arraigo de colonos sin capital, estimula la formación de entes cooperativos como instrumento poderoso al servicio del des. envolvimiento económicon. ${ }^{2}$

Esas ideals parecían originarse en la identificación apriorística entre las nociones de «cooperativas» y «desarrollo económico» estableciéndose entre ambas - desde un plano de conceptualizaciones abstractas - una relación de causalidad. Por lo demás, no resulta sencillo sustraerse a la fuerza de las apariencias: tal el caso de la imagen que sugieren en una primera y superficial aproximación intelectual esas sociedades cooperativas de regantes surgidas en una «colonia» de origen estatal, toda vez que los términos «colonia» y «cooperativas» evocan, casi subliminalmente podría decirse, la mancomunión de esfuerzos de pequeños productores independientes.

Dada la estrecha relación existente entre la culminación del proceso de apropiación de las tierras ribereñas y la aparición de estas entidades, la investigación se propuso indagar tanto en el origen cuanto en la composición y evolución de las mismas con el intención de aportar elementos que permitiesen desentrañar su verdadera naturalezi. Los resultados obtenidos prueban que, en esencia, las sociedades cooperativas constituyeron instrumentos de una apropiación de tierras de contenido decididamente elitista. Ello, a la par que entraña cuestionar las divulgadas concepciones sobre

1 Molins, Jaime W.: El Alto Valle del Rio Negro. Buenos Aires, 1919, pág. 41.-Mailhet, Luis D.: El Alto Valle de Río Negro. Buenos Aires, 1944, pág. 24. Toledo, Tránsito Leandro: Historia de la fundación y progreso de General Roca (R.N.), 1879-1899-1969. Buenos Aires, 1979, págs. ¿12 y 214.

2 Maida de Minolf, Esther Lidia: Colonia General Roca. Pionera en la colonización del alto valle rionegrino, en «Congreso Nacional de Historia sobre la Conquista del Desierto. Academia Nacional de la Historia», 1980, tomo 3, pág. 513. 
el papel que las mismas cumplieron en el desarrollo económico regional y aquellas otras no menos difundidas que aluden al hipotético fracaso de algunas, explica también que esas/sociedades nunca estuvieran constituidas - y mucho meros dirigidas - por el sector de pequeños propietarios.

Conceptualizar como elitistas a las cooperativas de riego y a la legislación que las generó no implica, en absoluto, postular la existencia de un contenido diferente, es decir democrático, en los decretos, leyes o disposiciones de tipo general por medio de los cuales se habían distribuido para entonces ya prácticamente en su totalidad las tierras arrancadas al indígena. ${ }^{3}$

En todo caso, la particularidad del marco legal sancionado entre 1907 y 1910 — tanto en su explícito carácter de normativa jurídica ad boc como en sus novedosos fundamentos de contenido progresista - no haría más que reflejar la profundización que había alcanzado hacia la época del centenario, el curso de desarrollo abierto en el país desde 1880 .

\section{La Sociedad Cooperativa de Irrigación Ltda. De General Roca}

En el proceso de apropiación y distribución de las tierras del valle del Río Negro es posible reconocer dos períodos cuya delimitación no se funda, sin embargo, en la posibilidad de señalar algún cambio o modificación de aquellas características que permiten definirlo en su totalidad como marcadamente elitista. Antes bien dichas etapas sólo reflejan el disímil grado de interés que suscitaran estas tierras a los ojos de los sectores dominantes en tanto fueron modificándose circunstancias que, a tales efectos, resultaban determinantes.

3 Cfr. Ockier, María Cristina: Propiedad de la tierra y renta del suelo: la especificidad del Alto Valle del Río Negro. Buenos Aires, 1987, págs. 10-30.-Ockier, Maria Cristina: Inmigrantes y élites en la distribución de la tierra de la «Colonia Roca» (Río Negro). anuario de la Escuela de Historia», 13. Universidad Nacional de Rosario, Rosario, 1988. 
Durante la veintena de años que median entre la «Conquista del Desierto» y fines del siglo pasado, la región no habría de provocar en el ánimo de los mentores y beneficiarios de la expedición militar atracción mayor a la que por entonces les despertaba la inmensa Patagonia. Las preferencias de los contribuyentes financieros de la campaña se orientaron decididamente hacia las tierras de Buenos Aires y del entonces territorio de La Pampa mientras las del sur del Colorado habrían de destinarse en lo fundamental a los beneficiarios de la ley de Premios Militares:

"La aristocracia ganadera que detentaba el poder supo guardar las tierras buenas y otorgó a sus servidores las mesetas pedre. gosas de la Patagonia...... ${ }^{4}$

Luego de transitar la larga y árida travesía que scpara al Río Colorado del Negro «ante ese espectáculo desolado y desierto, aunque grandioso» en el que la naturaleza parecía haber resumido todo lo ingrato, Darwin no había vacilado en exclamar que «aquella zona era la región maldita por excelencia». ${ }^{5}$

A su exigua productividad natural y a la considerable distancia que las separaba de los mercados, características entonces distintivas de la mayor parte de las tierras patagónicas, las aledañas al Río Negro sumaban la peculiaridad adversa de encontrarse sujetas a periódicas y devastadoras inundaciones, lo que «explica cómo hasta hace muy poco tiempo el público no se disputó las concesiones de tierras en el Río Negro». ${ }^{6}$

Así, el reparto inicial de las tierras valletanas quedó enmarcado en la legislación de tipo general sancionada desde 1878, conformada tanto por las leyes y decretos que habían sustentado de modo directo la operación militar de conquista (leyes del Emprés-

4 Gaignard, Romain: Origen y evolución de la pequeña propiedad campesina en La Pampa seca aruentina (el caso de la provincia de La Pampa). En «Desarrollo Económico», abril-junio 1966, vol. 6, núm. 21, pág. 63.

5 P. Pacottet-G. Ancibar: Los valles inferiores del Limay y del Neuquén. El Río Negro hasta Choele-Choel. «Boletín del Ministerio de Agricultura», Buenos Aires, 1913.

6 Ibidem. 
tito o de Premios Militares), como por aquellas disposiciones que regían por entonces la adquisición de las tierras fiscales (ley de Remate Público, de concesiones en venta o arrendamiento de considerables extensiones, etc.).

Correspondiéndose con las concepciones estratégicas que postulaban el establecimiento de una nueva línea de fronteras sobre el Río Negro, el poder ejecutivo sancionó un decreto complementario de la ya inminente operación militar. Dicho decreto disponía que una comisión de ingenieros militares explorase las márgenes del río con el fin de determinar los puntos más convenientes «al establecimiento de colonias agrícolas de familias europeas o indígenas o de colonias militares» las que deberían constituirse en baluartes para la defensa de la frontera a establecerse. Estas tendrían una superficie máxima de 40.000 hectáreas subdivididas en 400 lotes de 100 hectáreas y se deberían distribuir en todo el curso del río, a distancias iguales entre sí. ${ }^{7}$ En cumplimiento de tal disposición resultó trazada sobre el valle superior del río, la Colonia Roca (29-11-1883). Cubriendo una superficie de 41.563 hectáreas -incluyendo unas 3.500 destinadas a calles y pueblos- fue dividida en 442 lotes la gran mayoría de 100 hectáreas. ${ }^{8}$ Caben, sobre el particular, algunas importantes precisiones.

Pensada con los criterios propios de los tiempos coloniales donde 100 hectáreas constituían lo que hoy se designa como unidad económica de una familia de agricultores en «las tierras de pan llevar», esa superficie era a tales efectos -es decir, como base para el sustento de una familia campesina - absolutamente insuficiente antes de la solución del problema del riego, en razón de la exigua productividad natural de esas tierras (lluvias anuales de $150 \mathrm{~mm}$.). A comienzos de la década 1920, cuando las obras hidráulicas se hallaban prácticamente concluidas, el jefe de la Comisión

7 Decreto del poder ejecutivo del 5 de marzo de 1879, cit. en: Ramos, Juan Mario: Fortines del Desierto. Mojones de Civilización. Tomo 2. Buenos Aires, 1969. pág. 190. Para mayores detalles sobre la etapa de la Conquista del Desierto puede verse Ockier: Propiedad de la tierra..., págs. 4-10.

8 División de Catastro y Geodesia. Archivo de Mensuras (Viedma): Duplicado 420. Diligencia de mensura y subdivisión de la «Colonia General Roca efectuada en 1885 por el agrimensor José María Muñiz (103 folios), folio 52. 
Inspectora de la Dirección de Tierras y Colonias, capitán de fragata Justino Riobó, efectuó estimaciones sobre el beneficio líquido que era posible obtener con el cultivo de alfalfa, predominante por entonces. Consideraba que por tratarse aquél de un cultivo menos intensivo que el de frutales y viñedos era también menos remuncrador y concluía que una superficie de 100 hectáreas «es excesiva» pues resulta «superior a lo que necesita una familia agricultora para su mantenimiento y progreso, aparte de que en esta superficie nunca podrá desarrollar sus actividades con la intensidad que requieren cultivos de esta índole», proponiendo, en consecuencia que se redujesen las concesiones a 25 hectáreas. El desarrollo posterior de la región confirmaría las aseveraciones de Riobó pues, cuando la frutiviticultura se constituyó en la producción fundamental (hacia 1940-1950), la superficie promedio de las propiedades del típico frutiviticultor valletano - sujeto social mayoritario a mediados de la década de 1950 y pilar del vertiginoso desarrollo de las fuerzas productivas que caracterizarían a la economía regional durante ciertos períodos- habría de ser de alrededor de 10 hectáreas, y la inmensa mayoría de las explotaciones menores de 15 hectáreas. ${ }^{9}$

Las incursiones militares que siguieron a la expedición de 1879 con las que culminó la ocupación de la Patagonia, previa derrota y exterminio del indígena, habrían de volver anacrónicos aquellos planteamientos defensivos que tan sólo unos pocos meses antes abogaran por la nueva frontera sobre el río Negro. Pese a ello, la afectación de prácticamente el $80 \%$ de la superficie de su valle superior y de la casi totalidad de la del valle medio a la constitución de esas colonias agrícolas con lotes de 100 hectáreas se mantuvo, lo que explica que esa porción de las tierras ribereñas no resultase en un principio adjudicada en extensiones similares a lo que lo venían siendo el resto de las arrebatadas al indígena. El hecho de

9 D.E.R.-D.G.T. y C.: Comisión Inspectora de Rio Negro, 1919-1920. Pueblos Viejo y Nuevo. Allen $e$ Ingeniero Huergo y sus quintas. Colonia Agricola General Roca. Libro 295 (544 folios), folios 245, 401 y 402.-Dirección General de Irrigación: Cita de antecedentes sobre Intendencia Regional $V$ y varios. General Roca (Rio Negro) (mimeograflado), 1969.-Ballester, Rodolfo E.: El Valle del Rio Negro. Regadio y producción. Ferrocarril del Sud. Publicación núm. 16. Buenos Aires, 1924. 
que tierras de una productividad potencial tan grande hubiesen quedado desde entonces hipotecadas a un proyecto estratégico tan rápidamente dirimido, no dejaría de tener consecucncias ulteriores como se verá.

Unos pocos lotes de la Colonia Roca pasaron al dominio privado a título de cancelación de los certificados de la ley de Premios Militares en tanto otros fueron entregados a particulares «en concesión», régimen de tenencia provisoria en virtud del cual los beneficiarios debían cumplimentar ciertas obligaciones en plazos determinados a fin de estar en condiciones de solicitar la escrituración correspondiente.

La guarnición militar establecida en el «Fuertc General Roca» dio origen al primer asentamiento blanco permanente de la «Colonia». Su población - según el relato de Augusto Margueirat, inspector general de la Dirección de Tierras de activa, prolongada y decisiva participación en la distribución de tierras- estuvo inicialmente constituida por

"[...] soldados dados de baja [a los que se agregó] un contin. gente de familias alemanas que no pudieron subsistir dando lugar al decreto de 14 de diciembre de 1885 , por el cual se eximía del pago de los anticipos que se les habian hecho para su traslación y establecimiento, permitiéndoles abandonar la colonia". ${ }^{10}$

Contemporáneamente, varios de los concesionarios iniciales constituyeron la Sociedad Vitivinícola Sanjuanina a cuyo frente se encontraba Hilarión Furque quien dirigió, entre 1884 y 1885, la construcción del primer canal de riego con que contó la región. Aunque también participaron indios, criollos, algunos de los inmigrantes alemanes e incluso penados, la mano de obra principal fue aportada por los soldados de la guarnición por lo que habría de conocérsele como «canal de los milicos». Realizado con medios sumamente rudimentarios y sin respetar criterios técnicos, sólo

10 Dirección de Estudios Rionegrinos. Viedma (R.N.). Dirección General de Tierras y Colonias. Expediente núm. 10891-S-1911, fol. 52. 
alcanzaría a regar de modo muy precario unas 1.300 hectáreas, en medio de permanentes disputas entabladas entre los pobladores a propósito del manejo arbitrario del agua, de lo que dan cuenta los expedientes elevados a esos efectos al ministerio de Agricultura."

A las dificultades mencionadas deben añadirse las que provocaban los frecuentes embancamientos que afectaban al canal y la constante amenaza de las inundaciones, lo que explica que los escasos colonos que residían en la Colonia Roca.

"[...] se contentaban con vivir, sin mayores aspiraciones, y así corrieron los años sin que se note interés por adquirir sus lotes». ${ }^{12}$

Es que, cl atractivo para los inversores, como comenta Huret, residía ahora en otra parte:

"[...] comenzaba a cultivarse el trigo en el norte de Buenos Aires. Luego sobrevino un período de crisis, y el Río Negro quedó olvidadom. ${ }^{13}$

Tal situación habría de quedar patentizada en el informe presentado por el inspector Marco Antonio Rufino, en 1896. ${ }^{14}$ Del procesamiento de la información recabada por el funcionario en su minuciosa inspección, lote por'lote, se concluye que:

a) sólo un poco más del $6 \%$ de las «chacras» había salido ya definitivamente del dominio del Estado;

b) casi un $60 \%$ carecía de concesiones vigentes a la fecha de la inspección;

c) el $33 \%$ restante se hallaba concedido, pero de esos 145 lotes casi una tercera parte estaban abandonados, no habiéndose

11 D.E.R.-D.G.T. y C. Expedientes núm. 2880-F-1901; núm. 1921-Z-1907 y núm. 2547-A-1907.

12 D.E.R.-D.G.T. y C. Expediente núm. 10891-S-1911, folio 52 vto.

13 Huret, Jules: La Argentina. Del Plata a la Cordillera de los Andes. (Sin indicación del lugar ni de la Pecha de edición); Eugene Fasquelle Editor, ParísSociedad de Ediciones Louis-Michaud, París, pág. 359.

14 D.E.R.-D.G.T. y C.: Inspección practicada en la Colonia «General Roca» por el inspector Marco Antonio Rufino. (Libro 287), noviembre de 1896, ¿87 folios. 
todavía satisfecho, en la mayoría de los ocupados, las obligaciones impuestas por la legislación. De modo tal que, a más de una década de trazada la Colonia, todavía quedaban disponibles para la apropiación privada 387 lotes, un $92 \%$ de su superficie.

Apenas transcurridos dos años del relevamiento de Rufino el gobierno nacional decidió suspender la venta de lotes en razón de la precariedad del servicio de riego [...] hasta que se efectuasen en el canal las reparaciones indispensables para que pudiese suministrar agua suficiente para el riego de la Colonia. ${ }^{15}$

Las opiniones de protagonistas y observadores también resultaban coincidentes a la hora de señalar la falta de comunicaciones como otra de las circunstancias que conspiraban contra el desarrollo de la región. En tanto Rufino le atribuía el estancamiento y deterioro de las actividades económicas, Margueirat opinaba que una colonia situada a tanta distancia de los centros de población y mercados de consumo, no tenía cómo progresar. ${ }^{16} \mathrm{El}$ inconveniente del aislamiento quedó resuelto con el tendido del ferrocarril -construido por los ingleses en una conjunción de intereses económicos con objetivos esencialmente estratégicos del Estado argentino (disputa con Chile) - y sobre cuyas consecuencias inmediatas diría, años más tarde, Margueirat:

"La línea del Ferrocarril del Sud, prolongada desde Bahía Blanca hasta la confluencia del Neuquén, puso en inmediato contacto a la Colonia con la ciudad de Bahía Blanca y su puerto, facilitando la exportación de los productos debía haber traído como consecuencia la población y dalento de la Colonia. No obstante, los viejos pobladores continuaron su existencia vegetativa como en el timpo de la Colonia mixta de militares y civiles.

Las comunicaciones más fáciles por el ferrocarril, hizo que fueran al lugar personas de más largas vistas, quienes se penetraron de la riqueza inexplotada encerrada en el valle ${ }^{17}$

15 D.E.R.-D.G.T. y C. Expediente núm. 2733-A-1903.

16 D.E.R.-D.G.T. y C.: Inspección practicada en la Colonia \&General Roca» por el inspector Marco Antonio Rufino, y Expediente núm. 10891-S-1911, folio 52.

17 Ibidem. subrayado en el original, folio 52 vto. 
El texto citado resulta significativo desde un doble punto de vista. Por un lado, al atribuir al ferrocarril inglés y a la exportación de productos que aquél posibilitaba la población y adelanto de la colonia, el funcionario no hacía más que reflejar la visión dominante desde el triunfo político de Roca y de la denominada Generación del Ochenta. La producción de alimentos baratos y otros bienes de origen agropecuario para el capitalismo europeo en expansión y en asociación con él, constituía a los ojos de esos sectores, la única alternativa posible de crecimiento. ${ }^{18}$ Por el otro, porque explícitamente hacía portadores de tales ideas a las «personas de más largas vistas» que trajera el ferrocarril a las que contraponía a los pobladores más antiguos atados a una «existencia vegetativa». No obstante, la documentación disponible prueba que estos últimos luchaban como podían por la tierra y cl adelanto económico contra los obstáculos naturales, la burocracia y los sectores dominantes.

Pero los nuevos interesados a los que hiciera referencia el funcionario, habrían de encontrarse con la imposibilidad momentánea de obtener las tierras que deseaban dada la suspensión de las concesiones. Coincidentemente con la llegada del ferrocarril la vida de los pobladores se vio bruscamente conmocionada por la inundación de 1899. Este hecho impresionó a tal punto la memoria de los lugareños que hizo decir, años después, al ingeniero Julián Romero enviado a la zona por la Dirección Nacional de Irrigación:

"Todos recuerdan por qué asumió las proporciones de lo inolvida. ble la espantosa creciente que arrasó cuánto había en esa regiónn. ${ }^{19}$

La resolución de 1898 por la que se había dispuesto suspender la venta de lotes en la colonia fue ratificada luego de la inundación, medida cuyos fundamentos exponía Margueirat del modo siguiente:

18 Dadas la fase por las que atravesaba el desarrollo del capitalismo a nivel mundial y las estrechas relaciones económicas que unían a las clases dirigentes argentinas con las potencias hegemónicas del momento, esa forma de inserción en el mercado mundial comportaba para el país, dependencia y subordinación.

10 D.E.R.-Ministerio de Obras Públicas. Dirección General de Irrigación. Expediente núm. 1649-0-1907. 
"Habiéndose producido una inundación de todo el valle del río Negro, el año 1899 se comisionó al Inspector Señor Antonio Oliveira para que previa visita a la colonia General Roca, informara respecto a los perjuicios ocasionados a los colonos. Hecha la inspección se dio cuenta de que la mayor parte de las pobla. ciones y sembrados habían sido arrasados, el canal de riego cegado en parte de tal manera que era difícil y hasta inposible en muchos casos fijar el deslinde de las concesiones debido a que la mayor parte de los mojones habian desaparecido.

En tal situación se juzgó conveniente suspender toda concesión vista la imposibilidad material de indicar el lugar de los lotes y también la de que se hicieran cultivos sin contar con la servidum. bre de agua de riego.

Por decreto 27 de enero del corriente año se autorizó la venta de lotes en las colonias salvo en la colonia General Roca, hasta tanto se construyera el canal de riego que se consideraba indispensable para la explotación agrícolas. ${ }^{20}$

En virtud de lo expuesto, el funcionario aconsejó (1904) no modificar la situación de los concesionarios mientras no se ejecutaran obras de defensa contra las crecientes extraordinarias y se hiciese un canal con capacidad suficiente para alimentar con ricgo todas las tierras aptas para el cultivo insistiendo en que, antes de exigir a los colonos que cumplan sus obligaciones, corresponde facilitarles los modos de hacerlo. Fundándose en ello y en que en la Colonia Roca no era posible conceder lotes sin previamente hacer el replanteo y mojones, procedió a rechazar algunas solicitudes en 1904, y utilizando similar argumento denegó en 1906 la aceptación de otras peticiones que habían sido elevadas tres años antes por Luis Casterás, Miguel Muñoz, Da Ponte Riveiro y Agustín Vera. La numeración y fechas de los expedientes así como los apellidos, lugar de residencia de los solicitantes (todos de la capital federal) y la participación que cupo a los mismos en la historial posterior de la región permiten inferir que salvo una, se trató de

20 D.E.R.-D.G.T. y C. Expediente núm. 6207-V-1807.

Tomo XLVII 
presentaciones simultáneas efectuadas por los miembros del grupo que pocos años después impulsarían la sanción del decreto del 27 de septiembre de 1907. ${ }^{21}$

Es que, con el tendido del ferrocarril se renovaba el interés por las tierras del valle, aun cuando todavía el temido espectro de las inundaciones estaba al acecho. En ese sentido, el gobierno nacional ya había puesto en marcha estudios tendentes a dar una solución integral a la cuestión con el proyecto elaborado por el ingeniero italiano César Cipolett (1899) sobre regulación del caudal de los ríos Limay y Neuquén que dan nacimiento al Negro y su aprovechamiento para riego.

En tanto, y con la misión de investigar las dificultades que seguía planteando el sistema de riego de la Colonia, la Dirección General de Irrigación envió en abril de 1907, al ingeniero Julián Romero. Una vez inspeccionadas las obras, el funcionario elaboró un informe en el que, luego de explicar técnicamente las razones de las dificultades del canal nacional - nombre que se daba en los escritos al viejo «canal de los milicos»-y las posible soluciones, terminaba exponiendo los criterios a su juicio más convenientes para las futuras adjudicaciones de tierras en la Colonia. En tal sentido proponía la ejecución de las obras «sin el auxilio de los recursos que forman la renta de la nación» mediante la creación de un «fondo de irrigación» que habría de constituirse fijando a la tierra un precio que se aproximase al valor que le daban las transacciones particulares dado que, según su opinión, aquéllas se concedían por entonces a título casi gratuito (en alusión al importe de 2'50 pesos * la hectárea estipulado por la ley 4167) aconsejando un precio de 50 pesos por hectárea para integrar los recursos con los cuales ejecutar las obras necesarias para proporcionar riego a todo el valle. Por último, en lo concerniente a la futura adjudica. ción de las tierras, Romero estimaba que «para facilitar su adqui-

21 D.E.R.-D.G.T. y C. Expediente núm. 836-R-1904; Expediente núm. 975-M1904 y Expedientes núm. 3421-A-1903; núm. 3084-C-1904; núm. 3087-M-1904; núm. 3089P-1904; núm. 3094-V-1904.

(N. del l.). 
sición por parte de agricultores que carezcan de capital, podría concederse el pago en seis anualidades». ${ }^{22}$

Los antecedentes expuestos precedentemente fueron sin dudas tenidos en cuenta por el poder ejecutivo a la hora de promulgar una serie de disposiciones legales cuya aplicación iba a signar duramente la historia posterior de la región. Entre 1907 y 1910 con la firma del presidente Figueroa Alcorta y a instancias de su ministro Ramos Mejía fue sancionada una serie de decretos en virtud de los cuales fueron privatizados prácticamente la totalidad de las tierras aún bajo el dominio del estado nacional en los valles medio y superior del río Negro.

El primero de aquellos decretos fue promulgado por el gobierno nacional (27 de septiembre de 1907) como corolario de la solicitud de tierras efectuada por un grupo de particulares. En sus considerandos sostenía la «conveniencia pública de establecer condiciones especiales de población» para la colonia dados los costosos trabajos requeridos para poner sus tierras en producción, lo que colocaba a éstas en «situación excepcional y fuera del alcance de colonos desprovistos de capital»; y entendía, además, que era necesario limpiar, perfeccionar y prolongar el canal de riego existente, «obras que deben ser ejecutadas por los mismos propietarios, ya que el Estado carece por ahora de los medios requeridos para llevarlas a cabo». Para ello fijaba el precio de la tierra en cincuenta pesos la hectárea, el que sería reducido a 2'50 pesos siempre que los adjudicatarios constituyesen una cooperativa para irrigar total o parcialmente la colonia. (Repárese que se tomaban aspectos de la propuesta del ingeniero Romero, cambiándoles el sentido). ${ }^{23}$

Por otro lado, ordenaba que la Dirección de Tierras y Colonias investigase la situación de los lotes ya adjudicados a fin de verificar la satisfacción de las obligaciones a que estaban sometidas las concesiones procediendo a dictar —en caso que se constatare su incumplimiento- la «correspondiente declaración de caducidad». El artículo 6. disponía:

¿2 D.E.R.-M.O.P.-D.G.I. Expediente núm. 1649-O-1907.

23 Decreto reolamentando la enagenación de lotes aoricolas en la colonia general Roca (Río Negro). Ministerio de Agricultura. Buenos Aires, 1908, págs. 3 y 4.

Tomo XLVII 
"En la adjudicación de los lotes se concederá la preferencia a los solicitantes comprendidos en la petición presentada al Ministerio de Agricultura con fecha 16 de agosto ppdo., que ha dado motivo al presente decreto reglamentario $[\ldots] \ldots{ }^{24}$

Los nuevos beneficiarios quedaban obligados a dar cumplimiento a una serie de condiciones: cercar totalmente el lote, desboscar, nivelar y sembrar la cuarta parte de la tierra concedida dentro de los dos primeros años; en los dos siguientes debían, además, plantar 2.000 árboles para cada 100 hectáreas (200 frutales) y construir casa-habitación de tres piezas de material; por último, se obligaban a depositar antes de la toma de posesion - como garantía del cumplimiento de las restantes obligacionesmil pesos por cada lote de cien hectáreas. Este depósito - que podía ser satisfechos mediante bonos del gobierno que devengaban interés, además de estar prevista su devolución posterior- constituyó en los hechos una de las formas legales mediante las cuales se excluía a las mayorías de la posibilidad de acceder a la tierra. En efecto, a fin de evaluar el significado económico del depósito, téngase en cuenta que la remuneración mensual de peones y capataces oscilaba, en la época y en la región, entre 20 y 45 pesos respectivamente. ${ }^{25}$ En consecuencia, la nueva distribución de lotes «a cuya propiedad habían perdido sus derechos la mayor parte de los primitivos poseedores» ${ }^{26}$ se hallaba regida por obligaciones cuyo cumplimiento, de ser efectivamente exigido, suponía una cierta solvencia económica por parte de los beneficiarios.

De ese modo, y al tiempo que eran arbitradas disposiciones legales que preveían la caducidad de concesiones anteriores y el desalojo en plazo perentorio de los «intrusos», quedaba sancionado un régimen de excepción para la entrega de las tierras fiscales de la Colonia del que resultaban expresamente marginados «los colonos desprovistos de capital». La propuesta de reglamentar el

24 Ibidem, pár. 9.

25 Toledo: Historia de la fundación.... págs. 185 y 199.

26 Benedit, Juan Carlos: Los Valles del Río Negro, Neuquén y Limay. Buenos Aires, 1921, pág. 14. 
pago escalonado de la tierra como modo de «facilitar su adquisición por parte de agricultores que carezcan de capital», oportuna. mente elevada por el ingeniero Romere, terminó por ser incorporada a una legislación que vedaba a aquéllos, de moclo explícito, tal posibilidad.

Concretando la preferencia que el art. 6." otorgaba al grupo cuya solicitud había originado la precedente disposición, el poder ejecutivo dictó pocos días después un nuevo decreto. Por éste concedía 50 lotes a 26 peticionarios, 24 de los cuales recibían dos lotes de 100 hectáreas cada uno. Entre los beneficiarios figuraban los hermanos Piñeiro Sorondo (Patricio, Octavio y Miguel), Luis Casterás, Alfredo y Daniel Goytía, Da Ponte Riveiro, Ramón Lemos, Paúl Edel, el ingeniero Luis Huergo, Angel Azcué, José Guerrico, Alfredo Lacabanne, el doctor Manuel J. Cordiviola, Ricardo Frías, Horacio Guerrico. En tanto, otros 39 lotes eran reservados durante el término de 60 días «a pedido del Sr. Cernadas, quien en su gestión manifestaba que serían solicitados por vecinos de la Colonia y personas que en esa época estaban fuera de la Capital», según habría de comentar el ingeniero Eleazar Garzón, director de la Dirección de Tierras y Colonias. ${ }^{27}$

Con la sanción del decreto del 27 de septiembre de 1907 y fundándose «en la imposibilidad de aplicar en aquel paraje (la colonia Roca) los preceptos contenidos en los decretos reglamentarios vigentes», el Estado había promulgado una legislación especial para el reparto de las últimas tierras fiscales de la región. Los solicitantes cuyos pedidos originaron esas disposiciones especiales -las que también, como se vio, otorgaban a aquéllos la

27 D.E.R.-D.G.T. y C. Expediente núm. 6114. A propósito de las reiteradas menciones de nombres propios que aparecen en el texto cabe aclarar que ellas no implican, de parte de la autora, juicio valorativo alguno sobre las conductas de tipo individual. Los comportamientos de los hombres conciernen al historiador en tanto exteriorizan relaciones sociales de las que ellos son meros soportes; esto es, cuando tales conductas tienen la virtud de expresar y sintetizar en sí mismas el movimiento y la dinámica de una sociedad concreta.

Por otro lado, es de lamentar que dados los condicionamientos de espacio que necesariamente supone una publicación de este tipo, resulte imposible poder siquiera transmitir las particulares resonancias que guardan ciertos apellidos para cualquier lector familiarizado con la historia argentina. 
preferencia en la adjudicación de los lotes- fueron, por supuesto, sus principales beneficiarios. Se hace necesario, pues, intentar una caracterización social de al menos algunos de ellos a fin de comprobar si, como afirma Maida, «el texto del decreto refleja la preocupación del gobierno por facilitar al pequeño y mediano agricultor el acceso a la tierra» o si, por el contrario, se trató de una disposición que favorecía su apropiación por parte de unos pocos privilegiados. ${ }^{28}$

Patricio Piñeiro Sorondo, el más destacado de los miembros de este grupo, había sido funcionario del aparato estatal llegando a ocupar durante la presidencia de Manuel Quintana (1904-1906) el cargo de subdirector de la Dirección General Tierras y Colonias, organismo decisorio entre los que por entonces arbitraban el destino de las tierras públicas. Había arribado por primera vez a la zona a fines del siglo pasado, como oficial mayor de Secretaría General de Correos:

"Su misión era el tendido y vigilancia de la línea telegráfica hasta Chos Malal, a lo largo de la vía férrea, por cuenta del ejército, con motivo del amago de guerra con Chile. Adquirió campos en el lugar lo mismo que sus hermanos Octavio, Miguel y Lino, y en los primeros años [del siglo] viajó continuamente desde Buenos Aires a la tierra que tan fuertemente lo atrajom. ${ }^{29}$

Fue entonces cuando, según un autor, convencido de las capacidades potenciales de la región contagió su entusiasmo a un grupo de personas con las cuales habría de participar en la fundación de la Sociedad Cooperativa de Irrigación de General Roca. ${ }^{30}$

De allí que Margueirat, en oportunidad de referirse de modo

28 Decreto reglamentando..., pág. 1. Para mayores detalles sobre los mecanismos que en la práctica vedaron a las mayorías el acceso a las tierras conquistadas por el Estado argentino a las naciones indias. Cfr. Ockier: Propiedad de la tierra..., págs. 23-30.

29 Boero de Izetta, Carlota: Historia del Valle del Río Negro. «Revista de la Junta de Investigaciones y Estudios Históricos». Viedma, 1972, pág. 18.

30 Rodríguez. Antonio: El Alto Valle del Río Neoro. Emporio de riquezas. Buenos Aires, 1947, pág. 160. 
tan entusiasta a las transformaciones que se producirían con el ferrocarril y la llegada de aquellos forasteros que pronto advirtieron las riquezas que prometía el valle, comentase:

“[...] el primero que tuvo la visión clara de aquello fue el Sr. Patricio Piñeiro Sorondo quien solicitó la concesión de unos lotes, compró otros, inició la cooperación de capitales y constituyó la Sociedad Cooperativa de Irrigación).. ${ }^{31}$

Junto a su hermano Octavio, Patricio Piñeiro Sorondo había iniciado gestiones (agosto 1907) por las que cada uno obtuvo una concesión de 200 hectáreas en la Colonia Roca. ${ }^{32}$ Poco días antes de sancionarse el decreto del 27 de septiembre. Patricio Piñeiro Sorondo se presentó ante la Dirección de Tierras y Colonias ${ }^{33}$ manifestando su intención de establecerse en la Colonia Roca para dedicarse «a la agricultura, a la plantación de árboles forestales (sic) y crianza de reproductores» y solicitando, a esos efectos la concesión en venta de «dos chacras en cualesquiera de las designadas con los números $54,58,59$ y $66 »$, además del otorgamiento de «un plazo de 60 días para hacer la opción». Al día siguiente la Inspección de Colonias, a cargo de Augusto Margueirat, informó que uno de los lotes se encontraba libre de adjudicación y los otros tres se hallaban reservados para el Ministerio de la Guerra pero «que habiéndose retirado de la Colonia las fuerzas que estaban allí de guarnición nunca se hicieron trabajos». Aun cuando existían pendientes de resolución solicitudes elevadas con anterioridad por otros interesados, ${ }^{34}$ el mismo día el ingeniero Garzón elevó al Ministerio de Agricultura su informe recomendando dejar sin efecto la reserva hecha por la cartera de Guerra y aconsejando hacer

31 D.E.R.-D.G.T. y C. Expediente núm. 10891-S-1911, folio 52 vto.

32 D.E.R.-D.G.T. y C. Expedientes núm. 5003-P-1909 y núm. 5041-P-1909.

33 D.E.R.-D.G.T. y C. Expediente núm. 5512-P-1907. No obstante haberse consultado los boletines oflciales no pudo encontrarse norma legal alouna que dispusiese el levantamiento de la suspensión de las concesiones en la Colonia Roca, medida que tampoco aparece en los informes y expedientes analizados.

34 D.E.R.-D.G.T. y C. Expedientes núm 6599-0-1906; núm. 7034-M-1906; número 7076-C-1906; núm. 1812-C-1907; núm. 1817-D-1907; núm. 1956-C-1907; núm. 1859R-1907; núm. 5041-L-1907.

Tomo XLVII 
lugar a la petición por cuanto, según expresaba, «esta Dirección conoce al Sr. Patricio Piñeiro Sorondo y cree formará el establecimiento que se propone». Transcurrida tan sólo una semana de iniciado el trámite, el presidente Figueroa Alcorta firmó el decreto de concesión otorgándosele además al interesado el plazo pedido para ubicar los lotes. No obstante la elección fue tan rápida que el mismo día habría de entregársele a aquél los títulos provisorios con la firma de Garzón. Octavio Piñeiro Sorondo prosiguió tramitaciones similares caracterizadas por idéntica celeridad que le permitieron obtener otrals 200 hectáreas. Las gestiones de ambos hermanos culminaron dos años después con la firma de sendos decretos de Figueroa Alcorta por los que se le otorgaban los correspondientes títulos de propiedad. ${ }^{35}$

Mientras a los peticionantes de 1907 se les asignaban tres de los lotes que había ocupado anteriormente la Intendencia de Guerra, y el retiro de la guarnición militar de la Colonia (1902) constituía el argumento a que apeló Margueirat para satisfacer la petición de Patricio Piñeiro Sorondo, resulta oportuno destacar lo siguiente. Poco antes de la rápida y exitosa gestión de este último, ante las solicitudes de dos inmigrantes rusos, Jos Ulman y Manuel Zilvestein, Margueirat expresaba:

( [...] hay suficiente tierra baldía en Roca, donde podrán ubicarse los colonos rusos, sin necesidad de que tomen posesión de los reservados para el ministerio de la Guerran. ${ }^{36}$

35 D.E.R.-D.G.T. y C. Expediente núm. 5041-P-1909; núm. 5003-P-1909. Caben dos precisiones. La ley núm. 4167 difería el otorgamiento del título de propiedad hasta que se diese cumplimiento a las obligaciones de poblamiento y se abonase el valor total del terreno, para lo que establecía un plazo de seis ańos. En el caso que nos ocupa se hizo una excepción en consideración a que los recurrentes tenian regularizada su deuda por el precio de la tierra y habían cumplido een excesos las obligaciones de ley. En cuanto a la aludida celeridad en las tramitaciones no era de ningún modo algo excepcional, sino más bien lo contrario, cuando se trataba de personas suffcientemente influyentes. El caso más relevante en este sentido fue el protagonizado por Manuel Marcos Zorrilla quien obtuvo 17.200 hectáreas regables en el valle del Río Negro. Para mayores detalles véase Ockier: Propiedades de la tierra..., pás. 16-19.

36 D.E.R.-D.G.T. y C. Expediente núm. 1432-Z-1907. 
La utilización arbitraria que de los hechos solían hacer algunos funcionarios a fin de favorecer o desalentar las peticiones según quienes fuesen los interesados, constituye otro de los componentes elitistas que habría de caracterizar, particularmente desde 1880, la legislación sobre tierras públicas.

El doctor Miguel Piñeiro Sorondo, en tanto, venía dedicándose desde principios de siglo a operaciones vinculadas con tierras fiscales. El Poder Ejecutivo había aprobado en 1900 una transferencia a su favor de las acciones y derechos correspondientes a una extensión de 40.000 hectáreas ubicadas en el Chaco, superficie que integraba una inicial de 80.000 hectáreas que habían sido otorgadas a su cedente para colonizar. ${ }^{37}$ Simultáneamente, como propietario de certificados por la expedición al Río Negro y en calidad de cesionario de Rosario Guayaquil de Ferreyra había obtenido 4.100 hectáreas en el Territorio del Chubut, superficie que habría de transferir pocos años después a Florencio Martínez de Hoz. ${ }^{38}$

Carlos Cernadas, no sólo había sido gestor de la disposición legal por la que se habían reservado tierras para los solicitantes de septiembre de 1907, sino que su nombre es mencionado de modo explícito por varios de ellos como «representante legal de la empresa», en lo que pareciera una implícita referencia al grupo propulsor. Simultáneamente con la adjudicación de los lotes que se le habían otorgado en la Colonia, Cernadas obtuvo una concesión en venta de 1.151 hectáreas en Neuquén, extensión que había arrendado con anterioridad de acuerdo con disposiciones de la Ley núm. $4167{ }^{39}$

Manuel Belloni, italiano de origen, se había destacado en los primeros años del siglo como un fuerte adquirente de las tierras

37 La transferencia habia sido hecha en virtud de las disposiciones de una ley promulgada en 1891. Por la misma se eximía a beneficiados con enormes extensiones de tierras de las obligaciones contraídas con el Estado de introducir determinado número de familias agricultoras a condición de que devolviesen la mitad de la superflcie otorgada en Chaco y Misiones, y la cuarta parte en el sur de la República.

38 «Boletín Oficial», 5 de julio de 1907.

39 \&oletín Oficial», 21 de agosto de 1907 y D.E.R.-D.G.T. y C. Expediente núm. 6114-C-1907. 
recientemente incorporadas al Estado como producto de la «Conquista del Desierto». Como tal, realizó una presentación en 1900 por la que solicitaba plazo para realizar la mensura de una superficie de 10.400 hectáreas que le había sido adjudicada en amortización de certificados de premios por la expedición al Río Negro, de los que era tenedor en calidad de cesionario. Pocos años después se le ve gestionando el título de propiedad sobre 34.638 hectáreas adquiridas en condominio, la concesión en venta de la cuarta parte de una superficie de 10.00 = hectáreas de que era arrendatario en La Pampa de acuerdo con la Ley núm. 4167 y una nueva concesión en arriendo de otras 5.000 hectáreas ubicadas en el citado territorio (1910). Al tiempo que concretaba dichas operaciones, Belloni obtuvo por cesión cuatro lotes en la Colonia Roca dos años antes de sancionarse el decreto de 1907, constituyéndose de inmediato en uno de los más activos propulsores de la cooperativa de riego. ${ }^{40}$

$\mathrm{El}$ ingeniero Luis Huergo, «argentino ilustre perteneciente a una de las familias más honorables de la época» nacido en 1841 en la capital federal, había sido uno de los pocos argentinos de aquel entonces que, «niño aún, fue a instruirse al extranjero» regresando para ingresar en la facultad de Ciencias Exactas de la que egresó en 1870 con el título número 1 en Ingeniería Civil. Desempeñó muchos cargos oficiales, entre ellos el de miembro de la comisión que estudió los ríos Negro y Limay en 1878, decano de la facultad de Ingeniería, director de la construcción del puerto de Buenos Aires, ministro de Obras Públicas de la provincia de Buenos Aires y presidente del Congreso Científico del Centenario, según datos de la breve crónica que de su vida nos acerca Rodríguez. ${ }^{41}$

Entre esta pléyade de nuevos propietarios de la Colonia algunos lo eran, a su vez, de otras tierras en la zona. Tales los casos, por ejemplo, de Luis Casterás que poseía más de 1.000 hectáreas en cercanías de la confluencia; de Casimiro Gómez, proveedor del ejército y amigo del general Roca, propietario de grandes

40 Boletín Oflcial», 27 de marzo de 1900; 15 septiembre 1900; 26 de octubre de 1905 ; 8 de octubre de 1906 .

41 Rodríguez: El Alto Valle del.... págs. 137-139. 
extensiones en el valle inferior del río Limay y del juez nacional Daniel Goytía, gestor y principal beneficiario del decreto que daría origen en 1908 a la Sociedad Cooperativa de Choele-Choel.

En tanto, otro grupo de los favorecidos (Lacabanne, Manuel Cordiviola, Ricardo Frías, Horacio Guerrico, entre los principales) habrían de formar parte de la Compañía de Tierras del Sud, sociedad anónima constituida en 1908 de cuyo directorio participaron, el ingeniero Percy Clarke, gerente del ferrocarril del Sud, el doctor José María Rosa (h.), ministro de Hacienda y Finanzas de Roca, el doctor Julio A. Romero y el ingeniero Emilio Mitre. ${ }^{42}$

La extracción social de los principales miembros del grupo habría de evidenciarse hasta en sus hábitos y costumbres cotidianas lo que no pasó inadvertido para un observador agudo como Blasco Ibáñez quien, años después, rememoraba:

"Recuerdo una comida en una fonda de General Roca, a la que asistieron los chacreros de las inmediaciones, para saludar al gobernador del territorio. Eran jóvenes los más de ellos, de exquisitos modales y notable ilustración que se revelaba a las pocas palabras $[\ldots]){ }^{43}$

La propia Maida relata que la primera comisión de la Cooperativa, que tenía asiento en la capital federal,

“[...] estuvo integrada por notables pioneros de la región, algunos de ellos pertenecientes a importantes círculos de la sociedad por-

42 Luchetti, Celestino: Breve reseña histórica de Cinco Saltos. Colonia ala Picasa» R.N. Cínco Saltos, 1964, pág. 10. Simultáneamente a la sanción de la ley Nacional de Irrigación que facultaría al poder ejecutivo para ejecutar las obras de riego con el concurso de las empresas ferroviarias, la compañía adquiríb 10.000 hectáreas en la margen izquierda del valle inferior del río Neuquén. De dicha extensión unas 3.000 hectáreas se hallaban en el valle y habrian de ser las primeras en recibir el servicio de riego a partir de la construcción de las obras estatales. Habilitadas éstas, la Sociedad procedió a fraccionar y vender la tierra en pequeños lotes (entre 5 y 15 hectáreas) dando origen a la conocida como Colonia Picasa, resultando finalmente liquidada en 1910 no sin antes haber revendido al gobierno nacional las 7.000 hectáreas que restábanle sobre la seca meseta patagónica.

43 Blasco Ibáńez, Vicente: La Argentina y sus grandezas, pág. 744 , cit. en: Maida, Esther L.: La colonización de Vicente Blasco Ibd́nez y el contingente valenciano en el Alto Valle del Río Negro. Formación de la Colonia Cervantes. Viedma. 1971, pág. 15. 
teña como los hermanos Patricio y Miguel Piñeiro Sorondo, Ramón Lemos, Marcelo Costa Paz, Dr. Pablo Edel, Dr. Daniel Goytía, $\Lambda$ ngel Azcué y Dr. Aquiles Gareiso.

[...]

La acción de la 1. Cooperativa de Riego marcó el inicio de la etapa progresista de la Colonia Roca ya que fuertes capitalistas argentinos o de origen extranjero como Cordiviola, Hans Flüegel, Lavallol, Klapenbach, Belloni, E. Huergo, Canale y otros adquirieron grandes extensiones y fundaron importantes establecimientos agrícola-industriales dando su espaldarazo al desarrollo valletanon..44

La información disponible permite distinguir en la formación del grupo promotor - y a la vez principal favorecido del decreto de septiembre de 1907 y los que lo siguieron - la confluencia de tres sectores cuyos integrantes, amalgamados no sólo a través de relaciones económicas sino incluso, en casos, de tipo parental integraron un tramado social compacto y homogéneo. Ellos fueron: a) miembros del aparato estatal, es decir, personas que había formado, formaban o formarían parte de alguno de los poderes del Estado Nacional, de la provincia de Buenos Aires o de la Capital Federal; b) importantes adquirentes de tierras fiscales; y c) personas vinculadas a los capitales británicos que por entonces habían comenzado a operar en la zona, bien por intereses económicos, bien en calidad de profesionales asignados técnicamente a las obras de irrigación. ${ }^{45}$

La cooperativa inició los trabajos tendentes a la mejora del canal existente en 1908; más tarde obtuvo la aprobación de sus estatutos y la autorización para funcionar como sociedad anónima

44 Maida: Colonia General Roca, pionera..., pág. 514.

45 Resulta interesante destacar que posteriormente aparecerán integrando esa élite que promovió la legislación especial para obtener las últimas tierras flscales disponibles antes que le construcción de las grandes obras hidráulicas multiplicara enormemente el valor de aquéllas, algunos de los funcionarios del aparato estatal a los que suele llamárseles de carrera para distinguirlos de los políticos (electivos o no) y que por lo general permanecen en sus cargos cuando se producen los cambios de gobierno. Son esos funcionarios de carrera que hacen funcionar la burocracia estatal en favor de la élite y que en algunos casos se integran a ella como socios minoritarios, por así decirlo. 
(1911), alcanzando a regar durante su gestión alrededor de 17.000 hectáreas.

El hecho de que Patricio Piñeiro Sorondo y Ramón Lemos, dos de los socios que contaban con mayor influencia y relaciones en los más altos niveles gubernamentales, ocupasen durante varios períodos la presidencia de la cooperativa facilitó enormemente el accionar de la nóvel sociedad. La actividad del segundo de los nombrados resultaría particularmente eficaz:

([...] al residir por temporadas en la Capital Federal, donde le era posible encarar con éxito las continuas gestiones y trámites que debían realizarse ante las autoridades nacionales, en cuyos círculos era muy conocido y apreciadom. ${ }^{46}$

De ese modo pudo obtenerse el apoyo financiero del Estado para realizar parte de las obras que habían fundamentado la creación de la sociedad. Hacia fines de 1910 y cuando ya estaban en marcha las obras estatales de riego, le fue adjudicada a la Comisión Administradora del Canal Nacional de la Colonia Roca la cantidad de ochenta mil pesos destinados a la construcción de desagües, alambrado del canal, etc. ${ }^{47}$

Por otro lado, y apenas otorgadas las concesiones, no sólo fueron rápida y favorablemente resueltos los pedidos de algunos de los beneficiarios que solicitaban cambiar la ubicación de los lotes originalmente asignados, sino que también recibieron la aprobación gubernamental cualitativas modificaciones introducidas al texto original del decreto de 1907. La más significativa de ellas se originó en una presentación colectiva realizada, entre otros, por Pearson, el ingeniero Huergo, el doctor Cordiviola, Azcué, M. Piñeiro Sorondo, por la cual solicitaban fuese reemplazado el inciso a) del artículo tercero del decreto del 27 de septiembre de 1907 por la obligación impuesta a los concesionarios de Choele-Choel según el decreto de abril de 1908. La disposición cuya sustitución se pedía establecía

46 Toledo: Historia de la..., pág. 213.

47 \&oletín Offcial», ley núm. 784i3, 10-11-1910.

Tomo XLVII 
la «obligación de cercar, emparejar, desbocar y sembrar o plantar con capital propio, la cuarta parte de los lotes concedidos dentro de los dos primeros años, la mitad a los tres y la totalidad a los cuatro». Por decreto del 7 de mayo de 1908 —nótese que sólo habían transcurrido 35 días desde la sanción del decreto referido a Choele-Choel - el poder ejecutivo aprobó la solicitud fundando su decisión en razones de equidad y estableciendo para los concesionarios de Roca «la obligación de cercar totalmente el lote, nivelar, desboscar y sembrar la cuarta parte de la tierra concedida dentro de los dos primeros años», además de exigirles la plantación de dos mil árboles por cada 100 hectáreas de los que doscientos debían ser frutales. ${ }^{48}$

De ese modo - y una vez excluidos expresamente «los colonos agrícolas desprovistos de capital»- se procedía a reducir notoriamente la extensión original de tierras que debían sistematizar los concesionarios como requisito para obtener la propiedad definitiva, al tiempo que al eliminar de la redacción la obligación de que tales trabajos fuesen ejecutados «con capital propio» quedaba abierta la posibilidad — de hecho ampliamente utilizada por los titulares de las concesiones- de su cumplimiento mediante el empleo de arrendatarios.

En agosto de 1908, Lemos se dirigió al entonces ministro de Agricultura, Pedro Ezcurra, presentando una nómina de los accionistas de la cooperativa y comunicando que los mismos habían reálizado el depósito de garantía exigido y parado el $10 \%$ de las acciones suscritas. Luego de manifestar que la Sociedad Cooperativa se hallaba efectuando los trabajos preliminares para la construcción del canal de riego y que la falta de agua impedía a sus representados «el cumplimiento de la ley» con lo que éstos podrían haber dado «forma más visible a la posesión», planteaba la necesidad de que «se ordenase» a la Dirección de Tierras y Colonias tomar debida nota en sus registros de los lotes concedidos:

(En el deseo, pues de evitar a los accionistas un gasto mayor de veinte mil pesos, que les resultaría inútil, $\mathrm{y}$ a fin de prevenir tam.

48 D.E.R. D.G.T. y C. Expediente 1822-V-1908 y Expediente núm. 6926-V-1908. 
bién de su curso a solicitudes correspondientes a esos lotes, que pudieran intentar algunas personas invocand• sin derechos tarácter de ocupantes $[\ldots] 1{ }^{49}$

Menos de un mes después, iniciaba un nuevo expediente con la finalidad de peticionar para los accionistas de la cooperativa el beneficio de la rebaja del precio de la tierra a 2'50 pesos en virtud de haber llenado las condiciones exigidas por el Art. 5. del decreto de 27 de septiembre de 1907. Al expediente se adjudicaba un laudatorio informe de Margueirat quien, luego de recordar la cláusula y los cinco incisos correspondientes cuyo cumplimiento daba derecho a los adjudicatarios a la referida reducción del precio, y el hecho de que la solicitud de Lemos se fundaba en el cumplimiento de tres de los mencionados incisos concluía que:

«Esta Sociedad única en su género, formada para la colonización $v$ explotación de una tierras improductivas, desde muchos años que se creó la colonia debido a la falta de riego, es muy digna de apoyo por parte de los poderes públicos y conviene cooperar a su desen. volvimiento. El pedido que formula el Señor Presidente de la sociedad es justo por cuanto siempre habrá lugar antes de acordarse el título definitivo de propiedad a exigirse el pago de cincuenta pesos la hectárea, suponiendo que ne se cumplieran todas las disposiciones del decreto del 27 de Septiembre de $1907 \% .{ }^{50}$

El incumplimiento por parte de algunos de los beneficiarios de las adjudicaciones dispuestas en función del decreto de 1907 de las obligaciones relativas a la integración de los capitales a la cooperativa, quedaría probado por una resolución ministerial dictada en octubre de 1914. Por la misma se exigía que las sociedades cooperativas de irrigación de Choele Choel y Roca justificasen haber cumplimentado el inciso c) del art. 5..$^{\circ}$ de los decretos respectivos (referíase a la suscripción de las acciones) por cuanto esa era la razón por la cual se encontraban pendientes de resolución las

49 D.E.R.-D.G.T. y C. Expediente núm. 4488-S-1908.

50 D.E.R.-D.G.T. y C. Expediente núm. 5854-S-1908. 
solicitudes de títulos de propiedad de chacras ubicadas en esas colonias. ${ }^{51}$

La irrigación de la parte oeste de la Colonia dependió de la cooperativa hasta 1921 en que el Estado adquirió, luego de largas conversaciones, los canales e instalaciones para integrarlos a la red de regadío fiscal concluyendo de ese modo una trayectoria signada por un régimen de prebendas, excepcionalidades y ayuda financiera del gobierno.

El principal mediador de las gestiones que prepararon dicha transferencia había sido Ramón Lemos, activista permanente en todas las tramitaciones que era necesario encarar en Buenos Aires «en cuyos círculos era muy conocido y apreciado» y encargado en esta oportunidad de solicitar el apoyo estatal ante los gravísimos problemas de salinización de los suelos originada por la falta de desagües. ${ }^{52} \mathrm{El}$ problema venía de larga data y sobre las «consecuencias desastrosas» que iba a acarrear en el futuro la ausencia de los necesarios drenajes, ya había llamado la atención muy tempranamente el ingeniero Romero. ${ }^{53}$ Años después y con motivo de su inspección, Justino Riobó pudo comprobar los asertos de la opinión de Romero, ${ }^{54}$ cuestión sobre la que insistiría posteriormente, en más de una oportunidad, la Dirección Nacional de Irrigación. El ingeniero Rodolfo Ballester, funcionario regional de esa repartición, escribía en 1924 que la estadística de producción y cultivos venía registrando desde hacía tres años una disminución de la producción en las zonas donde primero se había iniciado el riego, estaciones de Cipoletti, Allen, J. J. Gómez y Guerrico (las tres últimas correspondían a regantes de la cooperativa), hecho que atribuía a dos causas. Por un lado, al agotamiento que venían experimentando los viejos alfalfares que requerían una pronta renovación y, por el otro, a un problema que destacaba como particularmente grave en la «Colonia Roca» donde prestaba servicio la cooperativa de Irrigación, que describía del modo siguiente:

51 D.E.R.-D.G.T. y C. Expediente núm. 4575-V-1914.

52 Toledo: Historia de la..., pág. 213.

53 D.E.R.-M.O.P. Expediente núm. 1649-0-1907.

54 D.E.R.-D.G.T. y C. Libro 295, folios 6 y 399. 
“En esa zona, la III, hay un problema más, la falta de desagües suficientes para descargar los excesos del riego, que ha hecho aparecer el salitre en muchas propiedades, problema que tiene su origen años atrás y que preocupaba ya en 1919 a la misma Cooperativa antes que pasara al Gobiernon. ${ }^{55}$

Como producto de las gestiones llevadas a cabo por Lemos ante las autoridades nacionales, la Dirección Nacional de Irrigación firmó con la cooperativa (ad referendum del PE), un convenio por el cual la entidad daba por cancelada con los 200.000 pesos moneda nacional ya recibidos en efectivo «la cesión a título oneroso de sus canales al Gobierno» quedando resuelta así, y tal como rezaban los considerandos del decreto por el cual se lo aprobaba, «una situación dificultosa para los regantes y para la Nación». ${ }^{56}$

Mediante esta operación, el Estado adquiría los canales y demás instalaciones que la Cooperativa había construido con los 50 pesos por hectárea que cada concesionario se obligaba a aportar a cambio de la rebaja que se le hacía en el precio de la misma. El monto mínimo 2'50 pesos que los beneficiarios pagaban por hectárea se compensaba, por decirlo de algún modo, con la contribución obligatoria que debía hacer la cooperativa para la construcción de las obras que regarían las tierras de sus socios. Por tanto, podría decirse que con la adquisición de los canales, el Estado se compraba a sí mismo. Compraba lo que se había pagado con su dinero - con el que había dejado de recaudar con la venta de la tierra a un precio nominal - con el agravante de que aquello que compraba adolecía de notorias deficiencias como habría de manifestarlo sin ambages la Intendencia de Riego, en 1920, al afirmar que en la «colonia

55 El citado funcionario se había desempeñado además como director de las obras del valle del Río Negro. Ballester, Rodolfo: Valle del Río Neoro Superior. Estaciones de Chichinales a Contralmirante Cordero. Estadistica de Producción y Cultivos. Año agricola 1924-1925. aRevista del Ferrocarril del Sud», año II, núm. 15. septiembre de 1926.

56 Ministerio de Obras Públicas-Dirección General de Irrigación: Reglamento para el aprovechamiento de las aguas del Río Neuquén en el Territorio Nacional de Rio Negro Departamento General Roca. Buenos Aires, 1927, pág. 38. 
Roca había un servicio de riego dudoso por ser derivado de una boca toma natural, con un sistema de desagües pésimo». ${ }^{57}$

Años después ya en oportunidad de una conferencia que dictó en el diario «La Prensa», Ballester rememoraba del modo siguiente aquellas circunstancias:

"La antigua Cooperativa siguió funcionando, pero trabado su desarrollo por dificultades financieras, problemas de desagües y alimentación de su toma, en marzo de 1921, el Estado se hizo cargo de la misma haciendo el servicio desde la red general de canales, cuya construcción se habia contratado con el ferrocarril del Sud. ${ }^{58}$

Tanto la gestación y desarrollo de la Sociedad Cooperativa de Irrigación de la Colonia Roca como el modo en que fueron finalmente resueltos los problemas de riego y particularmente de drenajes - recuérdese que el precio de las tierras había sido reducido a fin de que los concesionarios asegurasen el riego total o parcial de sus tierras y que el gobierno había otorgado una subvención para la construcción de desagües - resultan claros ejemplos del verdadero sentido que los sectores dominantes en la sociedad y el estado argentinos han dado a los términos privatización y estatización.

Incluso el propio Ballester, entusiasta defensor del espíritu que, en su opinión, había animado la constitución de esta cooperativa «ejemplo de labor individual y colectiva de los regantes», no dejaría de manifestar su desencanto cuando, a modo de balance sobre la gestión de la misma, expresó:

"[...] Lástima que su iniciativa fue anulándose en cuanto vieron al Estado emprender las grandes obras. Fenómeno general que cada día parece que tiende a hacerse más intenso. La esperanza del Es.

57 M.O.P. Dirección General de Irrigación. Intendencia de Río Negro o Superior. Memoria Anual. Año 1920.

58 Ballester, Rodolfo: El Río Negro. La Conquista del Valle por el regadio. Cultivos. Año agrícola 1924-1925. «Revista del Ferrocarril del Sud», año II, núm. 15, Revista «La Ingeniería». núm. 657 de julio de 1929. Reimpresión hecha por la Sociedad Rural de Río Negro. Buenos Aires, 1929. 
tado-providencia que ha de venir a salvar todas las dificultades, transforma la acción en peregrinación de postulantes.. ${ }^{5 \%}$

Aunque sin proponérselo, el funcionario no hacía más que poner al desnudo un aspecto crucial entre aquellos que contribuyen a explicar, entonces como ahora, la ríspida y debatida cuestión del déficit estatal. Excepcionalidades y privilegios de todo tipo, siempre a costa del erario público, han jalonado a todo lo largo de nuestra historia, excepción hecha de cortos interregnos, tanto la trayectoria de las inversiones extranjeras realizadas en el país como la de los negocios emprendidos por los sectores de poder.

La distribución de la tierra pública a partir del decreto que otorgaba preferencia al grupo promotor de la Cooperativa General Roca se efectuó en su mayor parte mediante concesiones de dos lotes. Si a ello se agrega el empleo, en casos, de prestanombres y algunas muy tempranas operaciones de compra efectuadas por algunos de los más pudientes y especialmente más avisados miembros del grupo acerca de la inminencia de la solución del problema del riego, se comprenderán las razones que confluyeron para configurar una estructura latifundista de la propiedad de la tierra en la porción occidental de la Colonia Roca.

Así lo atestiguaba Riobó quien, con motivo del relevamiento que efectuara en el Pueblo y quintas de Allen en 1920, iba a exponer con crudeza los resultados reales de esta política de tierras. En la parte general de su informe, luego de señalar los graves inconvenientes que ocasionaban a la agricultura la presencia del salitre en los suelos y la falta de desagües en la zona de irrigación, concluía:

"Hay además otro motivo - tal vez el más grave-- que determina esta situación de estancamiento de Allen. Nos referimos a la escasa subdivisión de la propiedad en las cercanías de este pueblo, el que se encuentra materialmente ahogado por grandes latifundios, como son los de Piñeiro Sorondo por el sur con sus cuatrocientas hec-

59 Ibídem, pág. 7. 
táreas aparentes y tal vez mil en realidad; el de Hans Flügel, con cerca de 1.000 hectáreas a continuación del anterior; el de la Sucesión Zorrilla con 1.000 hectáreas también, cerrando el paso por el oeste y un poco más allá el Doctor Manuel Cordiviola con 500 hectáreas, y asi siguen estos latifundios que han nacido al margen de la ley, burlando sus disposiciones y pisoteando su espí. ritu, para servir sólo de rémora al progreso de los pueblos, de las colonias y del paism. ${ }^{00}$

\section{Ija Socifedad Cooperativa de Choele-Choel Y El. «ACAParamiento del Dr. Goytía»}

Producida la inundación de 1899 , y como consecuencia de ella, la capital del territorio se trasladó desde Viedma a la isla de ChoeleChoel, situada en el valle medio del río Negro. Apelando a las ventajas que suponía la llegada del ferrocarril, el entonces gobernador Eugenio Tello solicitó al ministerio del Interior la creación de la colonia agrícola pastoril. Su propuesta quedó concretada un año después mediante la sanción de un decreto por el cual se procedía a trazar aquélla sobre una superficie aproximada de 30.000 hectáreas subdividida en 304 lotes de 100 hectáreas. Dos años después, a instancias nuevamente de Tello, se produjo el arribo de 70 familias galesas provenientes de la colonia del Chubut otorgándoseles a cada una un lote de 100 hectáreas de acuerdo con la ley de Tierras núm. 4167 por entonces vigente, las que de inmediato se abocaron a resolver siquiera fuera parcialmente el problema del riego. ${ }^{61}$ Los propios colonos - con la ayuda de un aporte estatal de 50.000 pesos - construyeron el conocido como «canal de los galeses» obra no obstante de modestos alcances ya que no alcanzaría a regar más de 7.000 hectáreas y sobre cuya falencia habría de informar a la Dirección de Tierras y Colonias A. Margueirat, luego de una inspección realizada a principios de $1907 .{ }^{62}$

60 D.E.R.-D.G.T. y C. Libro 295, folio 6.

61 Fulvi, Nilo J.: La Isla de Choele Choel. Una historia con altibajos, en: «Río Negro, pasado y presente». Buenos Aires, 1980, págs. 86-89.

62 D.E.R.-D.G.T. y C. Expediente núm. 1921-T-1907. 
En abril de 1908, y a semejanza de lo ocurrido en la porción occidental de la Colonia Roca, el poder ejecutivo dictaba un decreto para Choele Choel en cuyos fundamentos sosteníase la conveniencia de fomentar el progreso de las colonias nacionales dictando disposiciones especiales para algunas de ellas acordes con la peculiaridad de su ubicación, naturaleza del terreno o facilidades de irrigación por cuanto la Colonia Nacional de la Isla de Choele Choel no prosperaba en la proporción que debía hacerlo, entre otras causas principalmente, debido a la falta de riego que esterilizaba el esfuerzo de sus habitantes. Luego de manifestar que la necesidad de prolongar el canal de irrigación en esa isla en toda la extensión que lo permitía el nivel de su suelo, hacía indispensable la inversión de capitales de relativa importancia «para hacer producir a la isla en frutos privilegiados un rendimiento que compense los gastos hechos», que la experiencia ya había demostrado en el Chubut y la Colonia Roca las ventajas que a esos efectos suponía la formación de cooperativas de irrigación y que el gobierno debía estimular por todos los medios a su alcance la difusión de la cooperativa agrícola «que constituía uno de los elementos más poderosos de desenvolvimiento económico y una aspiración manifiesta del espíritu moderno», terminaba por establecer disposiciones similares a las arbitradas en 1907. El precio de 30 pesos fijado en este caso a la hectárea quedaba reducido a 2'50 pesos para aquellos adjudicatarios que constituyesen una cooperativa para irrigar total o parcialmente la colonia, finalizando la disposición el art. 6." que establecía:

"En la adjudicación de los lotes se concederá la preferencia a los solicitantes comprendidos en la petición presentada al Ministerio de Agricultura con fecha 23 de diciembre del año próximo pasado y la del 3 de febrero último que ha dado motivo al presente decreto reglamentario y en adelante según el orden de presentacións. ${ }^{6.3}$

Como se ve, y de modo casi idéntico a lo ocurrido en 1907 en la Colonia Roca, la legislación que arbitraba la entrega de tierras en la isla resultaba el corolario de la solicitud previamente

63 Boletín Oflcial, 3 de abril de 1908.

Tomo XLVII 
elevada por algunos interesados a quienes aquélla convertía en beneficiarios prioritarios y casi excluyentes de sus disposiciones. No es de ningún modo casual que uno de los peticionantes a quienes hacía mención el decreto, Daniel Goytía, hubiese resultado previamente favorecido con tierras en la Colonia Roca.

Transcurrida más de una década de otorgadas estas concesiones, la isla de Choele Choel fue inspeccionada por la comisión que encabezara Justino Riobó. El funcionario informaba que, para entonces, la superficie cultivada en la Colonia se hallaba circunscripta a la influenciada por el canal llamado de los galeses y abarcaba a lo sumo unas siete mil hectáreas en la extremidad noroeste de la isla, agregando:

"A excepción de las siete mil hectáreas a que acabamos de referirnos y de algunos lotes de la ribera que favorecidos por la humedad producida por las filtraciones del río pueden ser cultivados sin necesidad de riego, todo el resto de la Colonia se encuentra sin cultivos por carencia de agua para el riego. Podría decirse, que toda esta zona improductiva y abandonada es la que se encuentra bajo la influencia de la Cooperativa de Irrigación de Choele-Chnel y sus obras.

Nuestra visita a las chacras de los miembros de esta cooperativa, la mayoría de las cuales se encuentran incultas y deshabitadas; la recorrida efectuada por la extensión del canal construido para el riego de las mismas, como así mismo las impresiones recogidas entre los pobladores de esta Colonia, nos hace formar una opinión poco favorable a los propósitos reales de la Cooperativa de Irriga. ción de Choele-Choel). ${ }^{\text {of }}$

Tanto las cuestiones vinculadas al origen y formación de la cooperativa como las que tenían que ver directamente con las obras realizadas eran los hechos que, a juicio de Riobó, lo llevaban a formular tal opinión.

64 D.E.R.-D.G.T. y C.: Territorio de Río Negro. Pueblo Chole-Choel-Colonia Agricola Chole-Choel-Colonia Mixta Fortin Uno-Colonia pastorial Catriel. Tomo IV. 1919-1920 (Libro 294), folio 243. 
Sobre el primer punto, el inspector recordaba que el decreto del 2 de abril de 1908 había dispuesto una reducción del precio por hectárea siempre que los adjudicatarios de lotes formasen una sociedad cooperativa que llevase a cabo la irrigación total o parcial de la colonia, y agregaba:

“Esta disposición dio origen a la formación de la Cooperativa de Irrigación de Choele-Choel, constituida en su casi totalidad por personas radicadas en la Capital Federal y con ocupaciones completamente ajenas a la agricultura. Sin embargo, todas estas personas pronto fueron concesionarios de chacras en la Colonia, go. zando de la reducción de precio de que hemos hecho mención).. ${ }^{65}$

En cuanto a las obras realizadas, el funcionario expresaba que la referida a la construcción de los canales necesarios para el riego de las tierras de sus asociados constituía la obra fundamental e indispensable que debía haber encarado una cooperativa cuya finalidad era la irrigación; obligación que, de paso recordaba, había sido la condición exigida por el decreto del 2 de abril de 1908 . De acuerdo con el resultado de su inspección la tal cooperativa había construido un canal que estaba muy lejos de satisfacer los fines del decreto mencionado por cuanto la visible ineficiencia de su sección no permitía el paso del caudal necesario para la conveniente irrigación de las tierras cuyo precio era reducido por el hecho de ser regados con tal caudal. Por otro lado, el hecho de que la boca toma del canal de la cooperativa que debía servir 20.000 hectáreas se encontrase situado sobre el canal matriz construido por los galeses destinado para una superficie de 7.000 hectáreas, le llevaba a afirmar que el canal de la Cooperativa de Irrigación de Choele-Choel no tenía capacidad para irrigar la zona para la cual había sido proyectado.

Como producto de la comprobación de la insuficiencia de la obra que era, a su vez, causa y origen de la constitución de la aludida cooperativa, Riobó planteaba significativas reflexiones:

65 Ibidem. folio 244.

Tomo XLVII 
"[...] se presenta al espíritu la duda sobre si las deficiencias de la obra son una consecuencia de errores técnicos o el resultado deliberado de una farsa destinada a engañar al Gobierno y burlar al decreto del 2 de abril de 1908 mediante la construcción de aparentes obras de irrigación que permitirian obtener la conside. rable reducción de precio que establece el decreto referente». ${ }^{\text {to }}$

Ello demostraba, a juicio del funcionario, la imperiosa necesidad de que una seria investigación técnica de las obras realizadas por la cooperativa pusiese en claro el asunto a fin de que la superioridad pudiese resolver en definitiva sobre las concesiones vigentes, a partir de un cabal conocimiento tanto sobre el estado en que se encontraban dichas tierras como sobre los antecedentes que habían determinado tales concesiones. Y a modo de conclusión terminaba por plantear que la Dirección General de Irrigación tomase, como base de sus estudios, la investigación realizada por la comisión a fin de llegar a construir una sola red de canales que regasen toda la colonia, cosa que debería resultar factible y fácil una vez que el Estado se hiciese cargo de las obras cle ese canal y del de los galeses. ${ }^{67}$

Así ocurrió también en esta porción del valle. En junio de 1911 la Dirección General de Irrigación fue autorizada a firmar los contratos con la empresa del Ferrocarril del Sud la que, sin embargo, no aceptó el trabajo. De allí en adelante el tema del riego experimentó sucesivas dilaciones. Los conflictos suscitados entre los regantes por la utilización del escaso caudal de agua -motivo de reiteradas reclamaciones ante el gobierno a la firma de un decreto del presidente Irigoyen (1922), por el cual se creaba la Intendencia de Riego de Choele-Choel organismo que, sin embargo, tampoco dio solución a los problemas. Diez años después todavía persistían los inconvenientes y limitantes que se derivaban de la falta de un sistema eficiente de riego, como habría de atestiguarlo la detallada

66 Ibidem. folio 244. Subrayado en el original.

67 Ibidern. folio 244. 
memoria elevada por el entonces gobernador de río Negro Adalberto Pagano quien comentaba:

"Tiene relativamente escasa producción, no por la falta de feracidad de las tierras, que son de alta calidad [...] sino por la imperfección del sistema de regadío. Hoy se cultivan alrededor de 3.000 hectáreas [...]. Las obras [...] de la isla Choele Choel se van ejecutando por administración, pero con escasas partidas que no permiten abocarse de lleno a la construcción del edificio para la toma, base fundamental para irrigar una gran superficie».. ${ }^{68}$

La construcción de las obras por parte del Estado culminaría en 1953 no habiendo estado ausentes durante este largo proceso partidas de ayuda financiera votadas oficialmente para la cooperativa y sanción de excepcionalidades que habrían de permitir a sus miembros obviar, aunque no fuese más que temporalmente, el cumplimiento de las obligaciones que les imponía la ley. ${ }^{69}$

Llegados a este punto cabe preguntarse cuáles fueron -a la postre- los resultados reales de la aplicación del decreto de abril de 1908 y, nada más ilustrativo al respecto, que recurrir nuevamente a los informes de Riobó. Este relataba que, durante su actividad en la isla, la Comisión Inspectora se había visto en la necesidad de prestar atención a la insistencia con que se le comunicaba la versión circulante sobre un acaparamiento de aproximadamente 25 lotes realizado por Goytía:

(En Choele-Choel, todo el mundo habla de las 'Chacras de Goytia' como de una cosa reconocida y cierta, y se comentan y se condenan los procedimientos usados por este señor, para obtener chacras, mediante el tan socorrido sistema de los testaferros). ${ }^{70}$

68 D.E.R.: Gobernación del Territorio de Río Negro. Memoria presentada al Superior Gobierno de la Nación. Año 1933. Ing. Adlaberto T. Pagano, Gobernador. Viedma, 1934, pág. 17.

69 Fulvi, Nilo J.: La Isla de Choele Choel..., pág. 88.

70 D.E.R.-D.G.T. y C.: Libro 294, folio 247. 
Tales referencias, a las que no obstante se debían considerar como «veladas y tímidas denuncias» ya que sus autores en ningún caso habían querido realizar acusaciones formales alegando falta de pruebas materiales o su deseo de «no meterse en líos», habían llevado al funcionario a investigar con detenimiento la situación de aquellos lotes que, incluidos en el presunto acaparamiento, no hubiesen sido todavía escriturados en propiedad. Además de la unanimidad exhibida por colonos y pobladores al considerar a Goytía único propietario de los 25 lotes, la indagación había permitido comprobar, según relataba, el sentimiento generalizado de «condenación» que suscitaba el nombre de Goytía por «los procedimientos puestos en práctica para obtener ciertos lotes» de los que había desalojado mediante la violencia a sus primeros ocupantes. La repulsa popular por los «desalojos y violencias» de que habían sido víctimas los pobladores Porcel, Uvaldi, Molina y otros había provocado en los lugareños animosidad tal contra Goytía que:

“[...] el 25 de setiembre de 1909, estos colonos realizaron en el pueblo de Choele-Choel, un meeting de protesta contra la Cooperativa de Irrigación $[\ldots]$ en el transcurso del cual quemaron la efigie del Doctor Goytía, representada por un muñeco de paja [...]"."

Impresionado por estos hechos los que entendía un deber comunicar al director general, Riobó explicaba sin ambiges su sentir del modo siguiente:

"[...]a nuestro espíritu impregnado de un elevado sentimiento nacionalista, ha causado una impresión de pesar y de vergüenza al considerar que un Vocal de una Cámara de Justicia, un Magistrado de la Nación, es quien hay a llevado tanto trastorno y desper. tado tanta animosidad entre pacíficos pobladores, a quienes debemos creer deseosos de dedicarse exclusivamente a labrar honrada. mente su prosperidad, inediante las ennoblecedoras tareas de la agricultura). ${ }^{72}$

71 Ibídem, folios 276-277.

72 Ibidem. Polio 277. 
Sólo una concepción abstracta sobre el funcionamiento del Estado podían hacer olvidar a un funcionario como Riobó -capaz de develar como lo había hecho la verdadera naturaleza de estas cooperativas-, los alcances prácticos de la legislación a cuyo amparo habían nacido. No sólo quedaba sancionado el derecho prioritario que asistía a algunos pocos en sus peticiones de tierras sino que habían sido previstos los mecanismos legales que liberarían de intrusos o de «incumplidores» de la ley a las ya ocupadas. Los simultáneos procesos de apropiación elitista de tierras y desposesión de ocupantes anteriores a que daría lugar semejante legislación, resultaría expuesto con claridad por el propio Riobó cuando, a propósito de los avatares sufridos por Porcel, un «viejo veterano del Ejército Nacional» participante de la expedición al Río Negro y poblador de larga data, relataba los pormenores de la expulsión de aquél de la tierra luego de 10 años de ocupación efectiva de la misma:

( [...] en el año 1916, aproximadamente, el citado Porcel fue desalojado por la Policía a instancias y con intervención del Doctor Goytía, el cual exigió y obtuvo del desalojo el pago de la suma de cien pesos moneda nacional, en concepto de arrendamiento del lote $[\ldots]) .{ }^{73}$

La constatación de los explícitos actos de propiedad ejercidos por Goytía sobre ese y otros lotes afectados a concesiones aún en vigencia (desalojo de ocupantes anteriores, arrendamiento de la tierra, etc.) además de suscitar la áspera censura de Riobó por la manifiesta ilegalidad que los mismos entrañaban habrían de llevarlo a denunciar la práctica de la utilización de testaferros, sumamente generalizada entre los beneficiarios de esta particular legislación. A propósito de la exposición del caso de uno de los lotes inspeccionados, Riobó comentaba los términos de una carta que había enviado Goytía a uno de sus testaferros, en febrero de 1912, en la cual

73 Ibidem, folio 278. 
anticipándose a una probable inspección a sus tierras, decía al destinatario:

"[... Al Inspector no hay necesidad de decirle que $\mathrm{Ud}$. ha vendido la chacra. Cuando le pregunte sobre la chacra le dice que Ud. la trabaja y la ocupa personalmente. Para que se convenza que Ud. está en la chacra trasládese a vivir a la casa construida en la chacra 9, sección VII. A cualquier pregunta que le haga el Inspector Ud. le contesta que la chacra es de Ud. y que tiene cumplidas todas las obligaciones impuestas por la Ley».

Riobó recordaba que, para la fecha de esa carta, el lote en cuestión aún no había sido escriturado y que de acuerdo a la ley núm. 4167 y al decreto de 1908 los concesionarios de tierras tenían completamente prohibido transferir bajo ninguna forma lotes agrícolas en tanto no tuviesen los títulos de propiedad. Y concluía:

"Como no podemos pensar que el Doctor Daniel Goytía, Vocal de una Cámara Nacional de Justicia, no conociera el texto de la Ley 4.167 y su decreto reglamentario, tenemos el derecho de presumir que al enviar las instrucciones de referencia por las que induce a Velázquez a realizar actos tendientes a engañar a un Inspector de la Dirección de Tierras como es el de trasladarse a vivir a la casa construida en la chacra 9, Sección VII, para que aquél se convenza de que ocupa la chacra, y al aleccionarlo sobre las falsedades que debe decir al inspector, como son las que se desprenden de estos párrafos de la carta citada: 'Al Inspector no hay necesidad de decirle que $\mathrm{Ud}$. ha vendido la chacra' ... 'A cual. quier pregunta que le haga el inspector, Ud. le contesta que la chacra es de Ud.' ..., el Doctor Goytia ha procedido con el deli. berado propósito de burlar las disposiciones del Deoreco de 8 de Noviembre de 1906, reglomentario de la Ley de Tierras n. 4167 , que regía esta concesión.

Como un comentario final de este caso, es sugestiva la promesa de la publicación del trabajo literario de Velázquez y del obsequio 
de un reloj y cadena a que se refieren los primeros párrafos de la carta que comentamos». ${ }^{74}$

En otra de sus cartas Goytía reiteraba instrucciones del mismo tenor:

"Me han informado que en la isla está la comisión del Gobierno inspeccionando las chacras. Pidole me haga el servicio de estable. cerse Ud. en una de las poblaciones de las chacras $1,3,4,5$, de la Sección 12 y poner personal por mi cuenta en las otras poblaciones, para cuando valla (sic) la Comisión a esas chacras, Ud. los informa que está encargado de ellas, por cuenta del respectivo concesiona. rio; por separado le envío la nómina de los concesionarios de las chacras $[\ldots]$. Si le preguntan, si yo soy el propietario, Ud. les contesta, que sabe que yo era hace años el empresario $[\ldots]$ ). ${ }^{75}$

La exposición de los hechos y documentos ponía en evidencia, a juicio de Riobó, no sólo «la manifiesta mala fe» de Goytía al aleccionar a terceros para que informasen con falsedad a los inspectores de la Dirección de Tierras, sino también la irregular situación de los concesionarios tanto en lo referido al cumplimiento de las obligaciones de población, mejoras y cultivos como la de la «ocupación y explotación personal». ${ }^{76} \mathrm{Y}$ de modo similar a lo que habría de ocurrir prácticamente con todos estos beneficiarios, la facilidad con la que (salvo contadísimas excepciones) pudieron eludir las obligaciones de ley - para lo que durante años debieron contar si no con la complicidad al menos con la negligencia de los funcionarios intervinientes - contrasta con el celo con que esos mismos funcionarios defendían el cumplimiento de tales disposiciones cuando se trataba de otros interesados.

74 Ibidem, folios 278-279, subrayado en el original.

75 Ibídem, folio 282, subrayado en el original. La Inspección constató. además, la existencia de cartas apócrifas en las que los presuntos concesionarios manifestaban que las mejoras introducidas en los lotes «por el empresario Señor Goytia; lo habian sido por su cuenta y orden. Comparando dos de esas cartas la Comisión llamaba la atención sobre el hecho de que el papel era exactamente igual en ambas misivas, habian sido escritas en máquina idéntica y redactadas por la misma persona.

76 Ibidem, folio 282. 


\section{Blasco Ibáñez y la Cooperativa Cervantes}

El escritor español Vicente Blasco Ibáñez llegó a la Argentina en el mes de junio de 1909 con el propósito de dictar un amplio programa de conferencias. Ligado a la Argentina desde 1906 como corresponsal del diario porteño «La Nación» y pese a que aún no había escrito la que sería su obra más conocida, su llegada concitó un enorme interés al punto que se había constituido una comisión de recepción presidida por el escritor Rafael Obligado. ${ }^{77}$ Comenta Maida que la revista «Caras y Caretas»

"Se regocijó de la acogida dispensada por nuestro pueblo al escritor, cuyas proporciones no habian sido igualadas por ninguna de las recepciones hechas a hombres extranjeros)" [agregando que] "Lo esperaban más de 10.000 personas que, en agitada aglomeración siguieron el coche que lo condujo desde el desembarcadero de la dársena norte hasta el Hotel España). ${ }^{78}$

Durante su estancia en el país desarrolló una intensa actividad que incluyó, no sólo la aceptación de cargos honoríficos y la participación en variados actos sociales, sino también una agenda de viajes que lo llevó por muchas regiones del país, viéndosele en fotografías con los indios tobas del Chaco o con los ingenieros del ferrocarril en la frontera con Bolivia. ${ }^{79}$

En diciembre de ese año (1909) regresa a España y plasma en un libro (La Argentina y sus grandezas) las impresiones de sus recorridos por el país. Dedicado en su mayor parte a describir las provincias argentinas, dirá en él:

77 Maida: La colonización de..., pás. 8-10. Agrega la autora que sus actuaciones siempre fueron noticia e incluyeron, entre otras actividades, una estadía con el general Roca en la estancia «La Larga», reuniones con notables del momento, aceptación del cargo de socio honorario de la Academia Literaria de Buenos Aires, padrinazgo de una villa fundada por la colectividad española y agasajos varios. Agregando más adelante: aLa prensa siempre tenía oportunidad de fotograflarlo entre las figuras centrales de flestas de la colectividad española 0 de los círculos porteños». Ibidem, pág. 33.

78 Ibídem, pág. 10.

79 Ibídem, págs. 10-12. 
"El valle del río Negro sólo necesita habitantes y obras irrigatorias. El gobierno argentino ha atendido a esta última necesidad, decretando unas obras colosales que se están realizando actualmente en las orillas del Neuquén, cerca de la Confluencia [...]). ${ }^{80}$ (Recuérdese que en marzo de 1910 habian sido iniciadas las obras del Dique sobre el río Neuquén).

Impresionado por las potencialidades que entendía brindaba la Argentina de entonces, Blasco Ibáñez habría de mostrar algunas de las facetas de su personalidad en las siguientes expresiones que le atribuyera el periodista español Abelardo Fernández Arias:

“No comprendo por qué los intelectuales españoles no vamos a América para enriquecernos. Desde hace tantos años emigran desde España a América tantos seres incultos que no saben leer, bestias de cargas, incapaces de discernir y que llegan a América descalzos, sobre la cubierta de los buques como un ejemplar más del rebaño que se exporta, y en poco tiempo esa horda de ignorantes se enriquece y todos los días vuelven a España 'los indianos' con su fortuna insolente que nos humilla. Para que este fenómeno se produzca, $o$ en aquella tierra hay un exceso de riquezas, que basta alargar la mano para posesionarse de ella, o los americanos son una raza inferior que se dejan explotar por estos seres incultos que en nuestro país no nos sirven ni para labrar el campo. Quién duda que si los intelectuales vamos allá en poco tiempo conseguiremos en ri(quecernos). ${ }^{81}$

Sin duda, que esas intenciones fueron las que impulsaron al escritor a elaborar muy ambiciosos proyectos de adquisición de tierras públicas en la Argentina y su puesta en producción bajo riego. Para ello retornará a nuestro país a mediados de 1910 dispuesto a poner en marcha sus proyectos: uno en la provincia de Corrientes, otro en el Alto Valle del Río Negro.

80 Cit. en Ibidem, pág. 13.

81 Cit. en Ibidem, pág. 9. 
Oficialmente inició sus gestiones el 31 de agosto de 1910 cuando se presentó ante el ministerio de Agricultura solicitando, para sí y para un grupo de 39 personas de las que probaba ser apoderado según mandato otorgado en Valencia ante escribano público, 84 lotes en la Colonia Roca por un total de 8.169 hectáreas. Manifestaba que era su intención establecer en dichas tierras una colonia de agricultores españoles dedicados al cultivo intensivo con regadío, proyecto que tendría lugar baio las proposiciones siguientes:

"l."-Me obligo en numbre propio y de mis poderdantes a cercar de alambrado las citadas tierras, desmontarlas, roturarlas y ararlas. 2." - A construir en ellas habitaciones de albañilería para los colonos, sanas, amplias y cómodas.

3. - A crear por propia cuenta el riego para dichas tierras, colocando grandes máquinas elevacioras de agua en la orilla del Rio Negro, con bombas, motores, etc.

$4 .^{a}-\Lambda$ construir canales mayores y secundarios para la distribución de agua en las tierras, y a cumplir, además, con todas las obll. gaciones exijidas por el decreto reglamentario (se refiere al decreto) del 27 de setiembre de 1907)". ${ }^{82}$

La solicitud fue remitida a la Dirección General de Tierras y Colonias cuya división de Inspección de Tierras confeccionó al día siguiente una «Plantilla de los lotes libres en la Colonia Roca». ${ }^{83}$ En ella se determinaba que los únicos lotes aún fiscales en la «Colonia Roca» son justamente los 84 comprendidos por la solicitud de Blasco Ibáñez. Esta coincidencia de ningún modo puede ser interpretada como una mera casualidad sino, muy por el contrario, como derivación de las múltiples y variadas relaciones que había establecido Blasco Ibáñez durante su estancia en el país, incluso en las más altas esferas del poder. A propósito de las gestiones emprendidas comenta Maida que, siendo amigo del presidente Figue-

82 D.E.R.-D.G.T. y C. Expediente núm. 6602-V-1910, folios 1-7.

83 Ibídem, folios 13-14. 
roa Alcorta al igual que de su sucesor el doctor Roque Sáenz Peña, Blasco Ibáñez encontró «sin dificultades apoyos para poner en marcha su empresa colonizadora» y que incluso habría sido Figucroa Alcorta quien lo impulsó a intentar la colonización en el Alto Valle del río Negro. ${ }^{84}$

Por otro lado, la información proporcionada por la mencionada planilla de lotes libres en la Colonia Roca muestra que 80 tenían solicitudes pendientes aún de resolución (los 4 restantes eran lotes inferiores, más pequeños y ubicados en los extremos del valle), y que en 22 de esos casos existía más de una petición por lote. Este manifiesto interés por las últimas tierras susceptibles de apropiación privada de la región se explica si se recuerda que desde marzo de ese año se encontraban ejecutándose las grandes obras hidráulicas (dique regulador sobre el río Neuquén, canal aliviador y Gran Canal Fiscal) que resolverían el grave problema de las inundaciones y proporcionarían riego a las tierras del valle.

Esas circunstancias fueron expuestas por el director general de Tierras y Colonias, ingeniero Eleazar Garzón, en el dictamen presentado al ministro de Agricultura el 6 de septiembre de 1910 a raíz de la solicitud de Blasco Ibáñez:

"La Inspección de Colonias en su precedente informe manifiesta que los lotes cuya compra gestiona el recurrente se encuentran libres de adjudicación con excepción del señalado con el N." 370 que figura concedido a don Camilo Fernández en Junio de 1895, y anota los pedidos que para cada uno de dichos lotes han presentado varios interesados.

Es indudable que la colonización en la forma que la propone el recurrente sería sumamente ventajosa para el progreso y adelanto de aquella región, pues es notorio que sólo mediante la inversión de importantes capitales en trabajos de riego y desmonte, pueden destinarse aquellas tierras a la agricultura.

Por estas ligeras consideraciones (sic), la Dirección General se

84 Maida: La colonización de..., págs. 12, 13-14 y 16. 
permite apoyar la propuesta del Señor Vicente Blasco lháñez; pero como otras personas de reconocida responsabilidad han pre. sentado propuestas también ventajosas como la presente y la su. perficie disponible en la Colonia General Roca está casi limitada a la que se gestiona en este expediente, considera esta Dirección General que habría conveniencia en reducir a (150 hs.) ciento cincuenta hectáreas la extensión a concederse a cada uno de los solicitantes, con el fin de satisfacer los demás pedidos a que se ha hecho referencia). ${ }^{85}$

Como resultado de la solicitud de Blasco Ibáñez y en vista de las numerosas solicitudes de lotes de la Colonia General Roca el poder ejecutivo sancionó el decreto del 24 de septiembre de 1910, algunos de cuyos antecedentes habría de rememorar tiempo después Augusto Margueirat. Sostenía el funcionario que una vez demostrado el éxito de la sociedad cooperativa de irrigación de la Colonia Roca en el ensanchamiento y mejoramiento del canal existente, y ante el convencimiento de que eran necesarios capitales, no sólo para la ejecución de las obras a realizarse sino también para sostenerse los años que hubieren de pasar antes de obtenerse producción,

([...] se pensó en suspender las concesiones en la parte Este de la Colonia, fuera de la zona de riego, en circunstancias que el Señor Vicente Blazco Ibáñez, en su nombre y en el de varios agricultores residentes en Europa, se presentó solicitando la concesión de lotes, obligándose a ejecutar las obras necesarias para su irrigación, etc. Dicha presentación dio origen al Decreto del 24 de Setiembre de 1910, en el cual se establecieron las condiciones que regirian las concesiones que se hicieran en la zona Este de la Colonia). ${ }^{86}$

85 D.E.R.-D.G.T. y C. Expediente núm. 660?-V-1910, folio 8.

86 D.E.R.-D.G.T. y C. Expediente núm. 10891, folio 53. Nótese que Margueirat explicita que la presentación de Blasco Ibáñez, «dio origen» al decreto del 24 de septiembre de 1910 y que manifestaciones similares («petición presentada al Ministerio de Agricultura [...] que ha dado motivo al presente decreto reglamentario») habian fundamentado los decretos de 1907 (Cooperativa de Colonia Roca) y de 1908 (Cooperativa de Choele-Choel). Cabe, pues, aplicar a dicha legislación el comentario efectuado por un columnista a propósito de modiflcaciones puntuales en los aranceles de exportaciones e importaciones instrumentados en agosto de 1988 por el presidente 
Aquél comenzaba por manifestar que si bien en atención a la falta de riego las tierras ubicadas en la porción oriental de la «Colonia» no habían sido todavía enajenadas, tal dificultad podía ser salvada por la acción de los futuros adjudicatarios en razón de que los solicitantes declaraban hallarse en condiciones de cumplir las obligaciones respectivas y hacer los trabajos necesarios para obtener el riego de las tierras que gestionaban. Entendía el poder ejecutivo que seguían vigentes las razones que habían determinado el decreto de fecha 27 de septiembre de 1907 y que no existían inconvenientes que oponer a la concesión de dichos lotes, pero que eran necesarias condiciones especiales exigidas «la especialidad del caso» ya que se trataba de tierras de una excepcional capacidad productora, que debían «distribuirse entre el mayor número posible de colonos». Sin embargo, en su parte dispositiva el nuevo decreto repetía casi textualmente las disposiciones contenidas en el de 1907 registrando como única novedad la del artículo 4." por el que se estipulaba que, en ningún caso, se otorgaría el título definitivo de propiedad sin haberse comprobado el cumplimiento de las obligaciones (cercar, desboscar, nivelar, cultivar, construir población, etc.), a cuyo efecto debería haberse invertido un capital no menor de 300 pesos por hectárea. ${ }^{87}$

Días después resultaba sancionado con la firma de Figueroa Alcorta y su ministro Ramos Mejía el decreto de adjudicación de las tierras, en virtud de que:

"[...] el Sr. Blasco Ihañez, manifiesta que ha llegado al país una parte de las familias agricultoras que se comprometió a establecer en las tierras de la Colonia 'General Roca' y que, además, ha adqui. rido máquinas e implementos de agricultura, que ya han sido en. viados a su destino, circunstancias que permiten explicar la ur-

\footnotetext{
Alfonsín: $\&[. .$.$] para conocer la historia económica argeniina hay que estudiar todas$ las resoluciones de este tipo, que siempre tienen nombre y apellido». (Diario aLa Nación», 7 de agosto de 1988).

87 \&Boletín Oflcial». Adjudicación de lotes al naciente de la Colonia General Roca, 27 septiembre 1910.
} 
gencia que invoca. estando, por otra parte, satisfechos los requisitos establecidos por el decreto 24 de Setiembre ppdo.... ${ }^{88}$

Por el mismo se concedían doce lotes completos a otros tantos solicitantes y veintiséis de 50 hectáreas a los restantes, quedando reservados dos lotes para futuras obras de irrigación, con lo que se totalizaba, aproximadamente, 2.500 hectáreas.

¿Qué había sucedido? ¿Por qué la concesión quedaba reducida a 25 lotes cuando Blasco Ibáñez había peticionado 84 ? Es que las «otras personas de reconocida responsabilidad» que habían «presentado propuestas también ventajosas» a las que hacía referencia el director general de Tierras y Colonias en el dictamen citado supra, integraban los dos grupos que habrían de constituir la Sociedad Cooperativa del Este (véase el apartado siguiente) entre cuyos socios más destacados se contarían miembros prominentes de la Sociedad Cooperativa de Roca, como los hermanos Patricio y Octavio Piñeiro Sorondo y otras personalidades como Pedro Benegas, bodeguero y mendocino y fuerte propietario de tierras y su hermano Alberto, el doctor Eliseo Segura y su hermano Benjamín, el doctor Santiago Amadeo Doléris, el ingeniero José Cantutti, funcionario de la Dirección de Irrigación, los hermanos Luis y Pedro Cipolletti y el cuñado de éstos, Felipe Bonoli, entre otros. Así, el decreto de concesión a Blasco Ibáñez sería seguido casi de inmediato de otros dos (6 y 8 de octubre, respectivamente) por los cuales se concedían a esas otras personas un total de 37 lotes. Pero la limitación de la cantidad de tierra otorgada a Blasco Ibáñez no derivó de la sugerencia realizada en su momento por Garzón de acotar en 150 hectáreas la cantidad a conceder a cada peticionario puesto que varios de los beneficiarios de los decretos de octubre recibirían dos lotes de 100 hectáreas. Dado el cúmulo de datos resulta a todas luces claro que el gobierno, ante el interés concurrente de varios e igualmente influyentes grupos sobre las mismas tierras y considerando seguramente las relaciones de amistad, parentesco y económicas que ligaban a miembros de unos y

88 D.E.R.-D.G.T. y C. Expediente núm. 6602, folio. 9. 
otros, había optado — previo acuerdo general — por una solución negociada con la finalidad de satisfacer a todos. ${ }^{89}$

Escasos días después del decreto de concesión, Blasco Ibáñez cfectuó el depósito de 25.000 pesos «valor nominal en títulos del Crédito Argentino» por la garantía establecida por el decreto del 24 de septiembre de ese año, según reza el dictamen de la Contaduría; sin embargo, el decreto establecía que el depósito de garantía podía ser constituido en títulos públicos a «su valor de plaza». ${ }^{90}$

Cumplimentados así los primeros trámites para la concesión de las tierras Blasco Ibáñez desarrolló en el último trimestre de 1910 una intensa actividad en relación con su proyecto. Así, consigue el permiso para ejecutar en el lote núm. 316 las obras necesarias para la toma del agua para el riego de la futura colonia (decreto del 28 de octubre de 1910), recibe los títulos provisorios de propiedad previa firma de los pagarés anuales por cada una de

89 Cabe recordar aquí aquella solicitud de Ramón Lemos, en 1908, de que se ordenase a la Dirección de Tierras anotar los lotes concedidos a los miembros de la Sociedad Cooperativa de Roca, a fin de eprevenir $|\ldots|$ se dé curso a solicitudes $[\ldots]$ que pudieran intentar algunas personas invocando sin derechos carácter de ocupantes» y la respuesta de la repartición asegurando haber tomado debida nota en sus regisiros de las dichas concesiones: $4|\ldots|$ a fin de que en caso de que esos lotes sean solicitados por ou'os aconsejar su rechazo» (D.E.R.-D.G.T. y C. Expediente núm. 4428-S-1908), para comprobar de qué modo se terminaban resolviendo a nivel personal y oficial los intereses contradictorios, según fuesen los peticionarios. Por otro lado la apropiación elitista de tierras implica, como su contracara inseparable, la exclusión de las mayorías y la expulsión del «pobrerío» (Inspector Rufino). Este último fenómeno caracterizó especialmente a la adjudicación de tierras efectuada a Blasco Ibánez. En efeclo; cuenta Toledo que $\alpha[\ldots \mid$ en los campos que hoy forman la colonia Cervantes y sus adyacencias, se había arraigado un núcleo de crianceros criollos que aprovechaban los restos de tierras fiscales que allí quedaban, en donde habian establecido sus puestos, dedicándose a la ganadería en menor escala, que era el medio de vida de los moradores de esa campaña, [...]). «[...] pero un buen día $[\ldots]$ aparecieron comisiones formadas por dos milicos que recorrian los puestos notificando a los vecinos que debían abandonarlos, retirándose a otra parte, por cuanto aquellas tierras habían sido afectadas a la colonización [...]». «Y se desocuparon esos cientos de hectáreas que pasaron a sel propiedad de un colonizador de ilustre rango, un hombre de letras, un eminente escritor hispano, don icente Blasco Ibáñez [...]». Toledo: Historia de la fundación..., págs. 214 y 215.

90 D.E.R.-D.G.T. y C. Expediente núm. 6602-V-1910, folio 56 vto. La Contaduría agregaba: «Este depósito lo ha efectuado el Señor Vicente Blasco Ibáñez a su solo nombre y aunque es de suponer que la intención ha sido hacerlo también por sus representados, cree esta Oficina que es indispensable una expresa manifestación al respecto», manifestación que no aparece en el expediente. 
las concesiones e inicia gestiones pidiendo la modificación de la disposición referida a los materiales a utilizar en las viviendas que debía construir en los lotes, según el decreto pertinente. En lugar del ladrillo "frágil e imperfecto» que no ofrecía las garantías necesarias y que además redundaba en construcciones "más costosas» solicitaba hacerlas en cemento armado y madera para pisos y revestimientos, propuesta que fue aceptada y avalada por un decreto presidencial firmado por Sáenz Peña a condición de que el costo de cada vivienda no fuese inferior a 1.500 pesos. ${ }^{91}$

Simultáneamente, el escritor se abocó a la constitución de la Cooperativa del Riego prevista en el decreto de adjudicación y cuya finalidad quedaba expresamente aclarada cuando, luego de mencionar a sus integrantes, se explicitaba que la sociedad obedecía al propósito de:

"[...] obtener para sí el primero (Blasco Ibáñez), y para sus poderdantes los demás, los beneficios de la reducción del precio de los lotes hasta el mínimun de la ley, según el artículo quinto del decreto del Superior Gobierno de veintisiete de setiembre de $1907[\ldots]$ ". ${ }^{92}$

Para ello y en uso de los poderes que le otorgaran sus mandantes, designó a 9 miembros de la colectividad española de Buenos Aires como representantes cada uno de un grupo de cesionarios de las tierras a fin de que representasen a éstos en los actos relativos a la constitución de la Sociedad Cooperativa. Realizada la reunión constitutiva y redactados los estatutos, Blasco Ibáñez se presentó ante el ministerio de Justicia solicitando la aprobación correspondiente el 22 de noviembre de 1911. La Inspección de Justicia opinó favorablemente aunque entendía que previamente debía intervenir el ministerio de Agricultura en razón de tratarse de una sociedad de regantes. La Dirección General de Tierras y Colonias elevó el expediente al procurador general del Tesoro «con recomendación de despacho urgente» efectuando el funcionario algunas

91 D.E.R.-D.G.T. y C. Expediente núm. 9780-B-1910.

92 D.E.R.-D.G.T. y C. Expediente núm. 10891-B-1910 ,folio 94 vta. 
objeciones, la más significativa de ellas referida al hecho de que los estatutos «tienen una amplitud de fines que desnaturaliza el objeto principal que se propuso el Superior Gobierno Nacional al conceder beneficios para la adquisición de los lotes». Aceptadas rápidamente las observaciones por el recurrente, el presidente Roque Sáenz Peña firmó un decreto aprobando los estatutos de la sociedad y un par de días después, el 17 de diciembre de 1910, es decir a 25 días de iniciado el trámite, otro decreto autorizaba a dicha sociedad a funcionar como anónima» (con lo cual, también en este caso, la sociedad de regantes tenía de cooperativa apenas el nombre). El 28 de diciembre, apenas dos días antes de embarcarse nuevamente para Europa, Blasco Ibáñez daba por finalizados los trámites administrativos relativos a sus tierras reduciendo a escritura pública los estatutos de la «Sociedad Anónima Cooperativa Limitada de Irrigación, Colonia Cervantes, tal y como lo disponía el Código de Comercio». ${ }^{93}$

Vuelto a España, habría de desarrollar en su tierra natal una intensa campaña destinada a reclutar los primeros agricultores para sus proyectos de colonización. El desbordante entusiasmo que sentía habría de quedar reflejado en los comentarios que hiciera a un escritor francés:

“Voy a establecerme en la Argentina, en los confines de la Pata. gonia, en donde he adquirido vastos territorios, gracias a los 300.000 francos que me han producido las 100 conferencias dadas en un año. En adelante, sólo quiero ser un colono pero cuando tenga 20.000.000 volveré a París y construiré un hotel suntuoso en el bosque de Bolonia... tengo alma de conquistador y sueño con empresas capaces de asombrar al mundo". ${ }^{94}$

El primer contingente de inmigrantes arribó al valle del río Negro en marzo de 1911. No se piense que eran éstos los cesionarios, pues aun cuando no son muchos los nombres de valencianos que han podido ser detectados en las fuentes, lo cierto es que de

93 Ibídem, folios 93-103.

94 Maida: La colonización de..., pág. 41.

Tomo XLVII 
los hallados ninguno se corresponde con los de los beneficiarios originales de los lotes. A fin de dar comienzo a los trabajos, lo que presumiblemente habría ocurrido hacia el mes de abril, el escritor recurrió tanto a los labriegos valencianos como a jornaleros y contratistas.

Para realizar el desmonte, sin duda una de las tareas más rudas y difíciles, Blasco Ibáñez había adquirido una máquina de procedencia norteamericana. Sin embargo las características de ciertas especies típicas de la región, particularmente el alpataco, terminaron con la desmontadora y el trabajo debió continuar con método comúnmente utilizado basado en el pico y el hacha. ${ }^{\text {yi }}$

En consonancia con su espíritu moderno y grandioso Blasco Ibáñez había incorporado «dos máquinas emparejadoras 'Champion', dos máquinas de bordear (para la construcción de canales y acequias de riego), y dos motores 'Hart-Parr' (locomóviles) a nafta fuerza $52 \mathrm{HP}_{»}$ - lo que hoy llamaríamos tractores- que munidos de tres arados de cinco discos cada uno eran capaces de arar «una superficie de una hectárea por hora» lo que resultaba absolutamente extraordinario para la época y la región. ${ }^{\%}$

Para el riego de las tierras haba importado de Italia dos bombas centrífugas para cuya instalación debieron realizarse emplaza. mientos sucesivos cuando la primera construcción sobre la costa del río corrió peligro de ser arrastrada por el agua. Resuelto el problema se profundizó una excavación natural la que alimentadn a su vez por un canal oficiaba de reservorio desde el que se confiaba en extraer el agua de riego: no obstante el sistema nunca llegaría a funcionar obstruida casi permanentemente su boca toma con arena y malezas. Una inspección practicada en enero de 1912 - cuando ya las obras se encontraban virtualmente paralizadas- mostraría que se había construido una parte del canal distribuidor principal $(1.700 \mathrm{~m}$.) y una tercera parte de los secundarios $(8.000 \mathrm{~m}$.) de modo que, de haber funcionado el sistema de elevación mecánica

95 lbidem. págs. 29-30.

96 D.E.R.-D.G.T. y C. Expediente núm. 10891-B-1910, folios 37 y 45. 
del agua, el riego habría llegado a 8 de los 25 lotes que componían la Colonia. No obstante, sólo unas 50 hectáreas podrían haber sido efectivamente regadas puesto que se trataba de la única superficie sistematizada y que contaba con las acequias necesarias para ello. ${ }^{97}$

En lo referido a las tareas de desmonte y roturación de la tierra, la mencionada inspección constató que se habían desmontado unas 1.395 hectáreas de las cuales se habían arado 855 , no habiéndose realizado, empero, sino mínimas siembras. Por lo demás, la totalidad de los lotes habían sido alambrados y se habían construido unas 37 viviendas. De fierro, es decir chapa galvanizada, en su mayor parte o de ladrillo, las construcciones eran de dimensiones reducidas, 36 metros cuadrados las más amplias, habiéndose complementado el conjunto habitacional con un núcleo administrativo integrado por una casa principal, caballerizas y ranchos de peones ubicados en la chacra núm. 328.

No obstante, para fines de año la vida de la Colonia languidecía y se había agotado ya el ímpetu que hasta entonces animara a Blasco Ibáñez agobiado por las dificultades de todo tipo, particularmente financieras, que debía afrontar.

El desconocimiento de las peculiares condiciones de la región que harían de él un «improvisado agricultor» unido a su inexperiencia como empresario reflejada en garrafales errores en los cálculos de costos y períodos de retorno de las inversiones realizadas; las dificultades derivadas de un sistema de riego que, además de costoso por depender de un insumo como la nafta, adolecía de notorias falencias técnicas; el rápido agotamiento de sus generosos recursos pecuniarios provocado por una mala administración, constituyen algunas de las múltiples causas que diversos autores han señalado como determinantes del descalabro financiero en que terminó la experiencia colonizadora de Blasco Ibáñez en la región. ${ }^{43}$

97 Ibídem, folios 2, 21, 30, 42 y 45.

98 Toledo: Historia de la fundación.... pág. 215. Cér. además, del mismo autor págs. 215-219; Maida: La colonización de.... págs. 36-40 y Rodriguez: El Alto Valle.... pág. 143. 
Lo cierto es que el 22 de diciembre de 1911 Blasco Ibáñez se presentó ante el ministro de Agricultura solicitando la reducción del precio de la tierra a $\$ 2$ '50 y el otorgamiento de los títulos definitivos de propiedad.

A fin de fundamentar su petición elaboró un extenso escrito ( 7 folios a máquina de ambos lados) en el cual con su estilo grandilocuente describía tanto las dificultades cuanto los logros de la que calificaba «una labor de colonización digna de aprecio». Entre las primeras destacaba las provocadas por la sequía peculiar de la tierra, la falta de agua potable y la dura y espesa vegetación. Luego de destacar la velocidad y tenacidad, a su juicio «dignas de ser tenidas en cuenta» que habían caracterizado la marcha de los trabajos, pasaba a detallarlos de modo pormenorizado a la vez que enumeraba las maquinarias y material rodante existentes. En su exposición, el escritor no vacilaría en incurrir no sólo en notorias exageraciones, como cuando afirmaba tener 1.600 hectáreas desmontadas y haber construido 20 kilómetros de canales primarios, sino incluso en afirmaciones falsas como cuando aseguraba estar sembrando unas 700 hectáreas con alfalfa. Luego de describir la obra de riego hasta entonces «realizada en su parte más importante» y los fundamentos de un modernísimo y por demás ambicioso proyecto de sistema mixto de ganadería y agricultura que pensaba poner en marcha. Blasco Ibáñez concluía:

"Tan grande esfuerzo ha agotado completamente nuestros recursos pecuniarios. Hemos empleado en las obras de la Colonia todos nuestros medios económicos y además hemos apelado al crédito bancario que es el recurso supremo de casi todos los que trabajan; crédito que hoy nos agobia con las exigencias de plazos ineludibles. De aquí la petición que formulamos a V.E. solicitando se nos conceda el título definitivo de las tierras que hemos colonizado, previo pago de la cantidad convenida con el Gobierno. Necesitamos este título porque tenemos el propósito de hacer una operación con el Banco Nacional Hipotecario, operación de préstamo que nos permita regularizar nuestra situación económica $[\ldots]$ ). ${ }^{49}$

99 D.E.R.-D.G.T. y C. Expediente núm. 10891-B-1910, folios 8 vto. y 9. 
La solicitud terminaba expresando que el pedido se hallaba avalado por el cumplimiento de las condiciones de poblamiento exigidas por la ley de Tierras y Colonias y al tiempo que reclamaba la protección estatal, afirmaba:

“La ley con sabia precaución y el espíritu previsor de los gobernantes oponen ciertos obstáculos a la concesión de los títulos defini. tivos para evitar que los especuladores de tierras se apoderen de los terrenos públicos y los vendan después. Pero en el caso presente no se trata de una petición de títulos definitivos para vender luego los campos. Deseamos los títulos definitivos para hacer una operación hipotecaria y el producto de ella aplicarlo por entero a la continuación de nuestra obra colonizadora. Y de la rectitud y claridad de nuestras intenciones responde el que no intentemos hacer la operación hipotecaria en un banco privado o con un particular, sino que nos propongamos acudir a un establecimiento público del propio Gobierno, como es el banco Hipotecario Nacional). 100

En su reiterada manifestación de que el esfuerzo realizado había agotado todos sus recursos, Blasco Ibáñez no hacía más que reconocer la situación de quiebra a la que había arribado su ambiciosa experiencia rionegrina. El fracaso final de ésta fue, según una autora, «la culminación de una serie de momentos difíciles en los que abundaron deudas, préstamos nunca saldados y gravámenes de hipotecas sobre las tierras»; otro califica como de dramático el final de «la obra del colonizador ilustre ante los numerosos problemas creados por la falta de recursos para afrontar los pagos, al haberse agotado los cuantiosos fondos aportados de su haber literariom. ${ }^{101}$

También se recuerdan los entredichos suscitados entre el valenciano y los encargados de la construcción de las viviendas que aquél debía hacer levantar en cada concesión en razón de la falta

100 Ibídem, folio 9 vto.

101 D.E.R.-D.G.T. y C. Expediente núm. 10891-B-1910, folio 9; Maida: La colonización de ..., pág. 40 y Toledo: Historia de la fundación.... págs. 218-219.

Tomo XLVII 
de pago. Maida transcribe una carta que recibió de uno de los constructores, el italiano Ernesto Carizza, quien relataba no haber dado cumplimiento al contrato de construcción por cuanto «de cada tres casas construidas, se abonarían dos, quedando una de garantía. Como no se dio debido cumplimiento a esa cláusula, dejé el trabajo». Incluso, en ocasión de uno de sus viajes al valle, Blasco Ibáñez debió sortear una tensa situación en la que el constructor le reclamó e insistió en el pago de la deuda; ante la imposibilidad de poder convencerlo, aquél se alejó del lugar exasperado recomendándole a su administrador:

«No me empleen más gringos pues son muy huelguistas, tomen paisanos que será más fácil joderlos». ${ }^{102}$

Problemas similares habría de tener con los valencianos que llegaran entusiasmados por el «furor propagandístico» que cundiera en Valencia a raíz de la encendida campaña desarrollada por el escritor. El primer grupo arribó en los meses iniciales de 1911. ${ }^{103}$ Integrado por unas 25 a 30 familias de agricultores, el contingente fue transportado en carros hasta su lugar de destino:

"A pesar de que se habían construido algunas precarias casitas destinadas al alojamiento de los colonos, parece ser que debieron recurrir a carpas cedidas por el ejército argentino para cvitar que varios quedasen a la intemperies. ${ }^{104}$

Pronto comenzó la deserción de algunas familias no conformes con las condiciones de trabajo en tanto que otros las aceptaron inicialmente para desistir luego de trabajar unos meses. ${ }^{105}$ Cuando,

102 Maida: La colonización de .... pág. 34.

103 Ibídem, pág. 27. Cabe recordar que en los considerandos del decieto por el que se le concedieron las tierras a Blasco Ibánez y sus representados, en 1910, el poder ejecutivo habla aceptado la urgencia invocada en el hecho de que «el Sr. Blasco Ibánez maniflesta que ha llegado al país una parte de las familias agricultoras que se comprometió a establecer».

104 Ibídem, págs. 33 y 29.

105 Toledo: Historia de la fundación..., pág. 143 y Maida: La colonización de ..., pág. 33. 
comisionado por Margueirat para que informase sobre la pertinencia de otorgar los títulos solicitados por Blasco Ibáñez el inspector Cornejo visite la Colonia Cervantes, corroboratá el éxodo dc los valencianos:

«Actualmente son menos en número los colonos que existen que hace algunos meses vinieron. Una parte de ellos, que estaban a la espera del anhelado líquido que hace proficua a la tierra, desesperando por su tardanza consiguiente en llegar, prefirieron ausentarse en busca de trabajo inmediato y remunerador que les ofrecían las actuales cosechas de otras partes $[\ldots]$.

En la actualidad existen unas cuantas familias y como cuarenta y tantos hombres $[\ldots]$ ). (En realidad la inspección da cuenta de sólo dos familias, la de Jaime Ronda en el lote 317, y la de Jaime Verdún en el lote 324). ${ }^{106}$

Los testimonios orales recogidos por Maida, confrontados entre sí,

"[ [...] coinciden en la descripción de un cuadro lamentable [...] días de hambre y de vivir precario en medio de una desoladora situación. Frecuentemente no disponían para la compra de lo más necesario".. ${ }^{107}$

Toledo, quien entiende que sla obra del ilustre fundador de la Colonia Cervantes fue más que positiva», da cuenta sin embargo de los graves problemas que había provocado la falta de pago de sueldos y jornales a los trabajadores concluyendo que a raíz de ello el trabajo «se había paralizado, reinaba el caos y los obreros estaban en plena agitación y efervescencia»; más aún, asegura quc aquéllos «no cobraron sus últinios haberes». ${ }^{108}$

La inestable situación económica habría de provocar más de un encuentro serio entre Blasco Ibáñez o su administrador, y los colonos:

106 D.E.R.-D.G.T. y r. Expediente núm. 10891-S-1911, folios 33 vto., 23 y 26.

107 Maida: La colonización de ..., pág. 36.

108 Toledo: Historia de la fundación..., págs. ¿18-219. 
«Estos, que se agrupaban en cuadrillas para realizar los trabajos, se llegaron un día hasta la administración reclamando el pago que nunca llegaba. El escritor los quiso amilanar enfrentándolos con un winchester, pero uno de los jefes de cuadrilla le replicó amenazador, haciéndose eco de la protesta del resto de sus com. pañeros: 'Tiré nomás, matará a alguno de nosotros pero somos muchos y usted no saldrá vivo de aqui'),. ${ }^{109}$

El final es descrito por Maida del siguiente modo:

«En Cervantes, Blasco Ibáñez abandonó todo ante el inevitable desastre. Lo que podríamos llamar tradición oral de la zona cuenta que se marchó a tiempo de resguardar su existencia que peligró a merced de los indignados colonos, $[\ldots]$ ". ${ }^{110}$

Pese a la situación descrita, el trámite iniciado por Blasco Ibáñez solicitando los títulos definitivos de propiedad seguía su curso. En una primera instancia, resultó encargado de verificar las obras el entonces presidente de la Sociedad Cooperativa de Irrigación de la Colonia Roca, Patricio Piñeiro Sorondo. En nota del 27 de diciembre de 1910, aquél informaba a la Inspección de Colonias que en razón de tareas inherentes a su cargo:

“[ [..] recién en 25 ó 30 días podré dejar terminada la inspección de los terrenos del grupo colonizador representado por el Sr. Vicente Blasco Ibánez, al que se refiere su nota de fecha de ayer, lo que me permite poner en su conocimiento en ésta las razones de apremio que, verbalmente me ha expuesto el Sr. Blasco Ibáñez). ${ }^{111}$

De esta manera, apelando a argumentaciones que pudiesen justificar la rápida resolución de sus peticiones - como ya había ocurrido en oportunidad de obtener las concesiones- Blasco Ibáñez lograba ahora el activo concurso de Piñeiro Sorondo, su amigo

109 Maida: La colonización de ..., pág. 36.

110 Ibidem, pág. 40.

111 D.E.R.-D.G.T. y C. Expediente núm. 10891-S-1911, folio 16. 
personal, quien no vacilaba en empeñar para ello las decisivas influencias de que gozaba en el gobierno central.

Acto seguido, Augusto Margueirat ordenaba al inspector de colonias Emilio Cornejo que, previa visita al terreno, informase detalladamente sobre: el capital social de la Cooperativa de Irrigación Cervantes; la división proporcional de ese capital por el número de concesiones y la tasación de todo lo que estuviese enclavado al suelo y constituyese capital fijo en cada concesión (casa habitación, corrales, cercos, piletas, graneros, caballerizas, plantaciones de árboles frutales y forestales, alfalfares y cultivos generales, etc.). Al recordar que en su presentación Blasco Ibáñez había incluido como capital a computarse maquinarias y ganado de labor, Margueirat estimaba conveniente dividir el total proporcionalmente por el número de concesiones, por cuanto:

«[..] es de suponer que con un propósito de economía, los mis. mos asociados de la cooperativa, han aunado sus esfuerzos para la adquisición de útiles de labranza, vehículos, ganados, etc. lo que no perjudica sino que beneficia los trabajos de la coleotivi. dad, $[\ldots]) .{ }^{112}$

Pese a sostener que la necesidad de conocer todo minuciosamente obedecía al propósito de saber si se habían radicado en cada lote los trescientos pesos moneda nacional por hectárea fijados en el artículo 4..$^{\circ}$ del decreto del 4 de octubre de 1910, la intencionalidad que entraña el párrafo precedentemente citado es clara. Conocedor de la real situación de esas concesiones, Margueirat se apresuraba a predisponer al funcionario que debía realizar la inspección y sutilmente lanzaba la idea de una asociación de capitales que, de hecho, diluía las obligaciones estipuladas por ley para cada concesionario.

Sólo 20 días le demandó al inspector Cornejo la presentación de un extenso informe compuesto de un cuerpo central ( 28 folios) y otro de anexos conteniendo cálculos de costos, detalles de las

112 Ibídem, folio 16.

Tomo XLVII 
maquinarias y datos conexos. Siguiendo las instrucciones recibidas efectuó un detalladísimo relevamiento de las mejoras existentes en cada lote y de la obra de irrigación «que ha sido la más costosa de todas y exigido enormes esfuerzos», manifestando que:

(De todo lo que antecede se desprende que las chacras enumeradas están totalmente alambradas y comunicadas entre sí por portones, desmontadas en parte o en todo, así como las calles intermedias, en su mayor parte limpias y roturadas en igual proporción, muchas con canales hechos y otras próximos a hacerse una vez que terminen otros trabajos de importancia en actual ejecución y que todas tenían ya sus correspondientes casas de buen aspecto y sólida construcción y su parte de terreno arado y listo para ser sembrado una vez que empieze a correr el agua tan indispensable, en forma normal y sistemada (

Para terminar concluía que, en un corto lapso de tiempo, se había desarrollado una suma de trabajo muy importante que representa no sólo un fuerte capital comprometido en él, sino un empuje y una entusiasta energía poco comunes dignas de ser bien apreciadas.

Al precedente informe se añadió el elaborado por Margueirat quien en términos laudatorios explicitaba las razones que a su juicio justificaban la entrega de los títulos de propiedad solicitados por Blasco Ibáñez. En su necesidad de disfrazar el evidente carácter de testaferros de los 37 adjudicatarios de tierras, presuntos representados de Blasco Ibáñez, luego de recordar que se trataba de concesiones «nominales e individuales» aludía al «esfuerzo mancomunado de los concesionarios». Luego, en una curiosa interpretación de la letra del decreto de concesión sostenía que si bien era obligación de cada concesionario invertir $\$ 300 \mathrm{~m} / \mathrm{n}$ en mejoras y cultivos, el haber reducido el precio de la tierra a todos aquellos que constituyesen cooperativas de riego «lleva al ánimo el convencimiento de que la mente del poder ejecutivo fue facilitar la asocia-

113 Ibídem, folio 33 . 
ción de los capitales, mancomunando el esfuerzo para la mejor, más acertada y económica explotación de la tierra». De lo anterior concluía la necesidad de que el monto total de capitales sociales se dividiese proporcionalmente por el número de concesiones. No obstante el art. $4 .^{\circ}$ del decreto del 24 de septiembre de 1910 había sido bien explícito. Establecía que en ningún caso se otorgaría el título de propiedad sin haberse comprobado el cumplimiento de las obligaciones (cercar el lote, construir una población, desboscar y nivelar la mitad de las calles circundantes y sembrar el $25 \%$ de la concesión) «a cuyo efecto deberá haberse invertido un capital no menor de 300 pesos por hectárea». Pese al abultamiento de las cifras, a considerar como inversión egresos no procedentes (pozos de agua que no funcionaban, maquinarias y ganado de labor) y a su particular interpretación de la letra de la ley, Margueirat no podía dejar de reconocer que la totalidad de los capitales no alcanzaba a los 750.000 pesos que corresponderían a las 2.500 hectáreas, y que «lo que falta para completar las obligaciones es la plantación y sementeras». No obstante, y retomando casi textualmente las argumentaciones utilizadas por Blasco Ibáñez, destacaba que lo hecho en tan corto lapso representaba «un esfuerzo poco común, un aporte de energías y capitales, caso único en las colonias nacionales» y que era «poco en relación a lo que ha de hacerse, pues al punto que se ha llegado no es posible parar sin ir a la ruina, mientras que perseverando se llegará a la meta». Por último y a modo de conclusión de su parecer, expresaba:

"[...] aun cuando lo hecho y los capitales introducidos no alcanzan a los 300 pesos por hectárea, no habría ningún perjuicio en otorgar el título definitivo de propiedad, posibilitando asi a los adjudicatarios el realizar una operación de crédito que les permi. tiese llevar a buen fin la empresa). 114

Al día siguiente la División de Contabilidad informaba que oídos los concesionarios se encontraban en mora por el pago de la primera letra que había vencido el 4 de octubre del año ante-

114 Ibídem, fols. 53, 54 vto. y 55.

Tomo XLVII 
rior, estimando la deuda global en $\$ 21.434$ '40 cuyo pago debía ser previo al informe de Contaduría. Añadía, la mencionada oficina, que el recurrente en su carácter de apoderado había infringido «el inciso $3 .^{\circ}$, artículo 28 , de la ley de sellos vigente». ${ }^{115}$

Al tiempo que se producía el despacho anterior, Blasco Ibáñez inició un nuevo expediente en el que, en calidad de presidente de la Sociedad Cooperativa de Irrigación, y en nombre de todos sus integrantes, solicitaba se hiciese llegar al «beneficio consignado en el Decreto de 24 de setiembre de 1910, según el cual debe cederse la tierra al precio de 2'50 pesos la hectárea a los que hubiesen hecho en ella obras de irrigación». ${ }^{116} \mathrm{El}$ mismo día de la presentación anterior, Margueirat aconsejaba hacer lugar a lo solicitado en atención a

115 Ibídem, folios 60-61 y 75 vto. La utilización discrecional de variados argumentos, en este caso el relativo a la falta de reposición del impuesto del sellado por parte de los solicitantes, constituyó en la práctica otra de las formas en las que se manifestó el carácter no democrático de la legislación sobre tierras públicas. En efecto, y como lo demuestra cabalmente la documentación analizada en muchas oportunidades tal habría de ser la razón aducida por los funcionarios para disponer el archivo de expedientes, según fuesen sus iniciadores. En el caso que nos ocupa. el mismo día en que se dicta la resolución exigiendo el pago, el recurrente efectuó el correspondiente depósito en el Banco de la Nación Argentina. En otras circunstancias, esos mismos funcionarios apelaban al argumento del cumplimiento estricto de la letra de la ley, como habría de ocurrir, por ejemplo, con la obligación de ocupar personalmente los predios que se solicitaban. En un expediente tramitado durante los años 1908-1913 por varios colonos de Choele Choel pidiendo se les permitiese escriturar definitivamente sus predios sin obligarles a esperar los seis años que la ley estipulaba para ello, los funcionarios intervinientes (Deheza, Garzón, Margueirat) habrian de insistir de modo particular en la necesidad de que los recurrentes hubiesen dado cumplimiento a la obligación de poblar y cultivar personalmente sus predios a fin de que sus solicitudes pudiesen ser consideradas. (D.E.R.-D.G.T. y C. Expediente 2393-S-1908).

En otra tramitación iniciada el mismo año que la anterior, la petición de varios colonos también de Choele Choel para que se dispusiese una prórroga de la cuota anual por el pago de la tierra dada la prolongada sequía que había asolado la región (los solicitantes carecian del beneficio del riego) resultaría finalmente rechazado en virtud de una Resolución de mayo de 1911 que estipulaba no haber lugar a presentaciones colectivas. (D.E.R.-D.G.T. y C. Expediente 3091-V-1908). Y aunque pareciera que la tal resolución no era aplicable al caso de marras por cuanto a rbitraba sobre hechos (en este caso la solicitud) producidos con anterioridad, algunas disposiciones legales podían llegar a tener, según los casos, un curioso alcance retroactivo. Tal lo ocurrido en la Colonia Roca una vez sancionado el decreto de 1907. Cantidad de solicitudes de antiguos pobladores presentadas con anterioridad a dicha disposición habrían de ser resueltas negativamente con posterioridad a la misma con el argumento de que dichas solicitudes no encuadraban en las disposiciones del mencionado decreto.

116 D.E.R.-D.G.T. y C. Expediente 545-S-1912. 
que los concesionarios habían constituido una sociedad cooperativa de irrigación «que ha ejecutado las obras que permiten regar los lotes» correspondiendo en consecuencia la rebaja de precio a que tienen derecho de acuerdo con el decreto citado. ${ }^{117}$

El dictamen final del director de Tierras y Colonias sobre las solicitudes de Blasco Ibáñez — la reducción del precio de la hectárea y el otorgamiento de los títulos de propiedad- se produjo el 26 de enero de 1912. En relación a la primera se expedía favorablemente aconsejando se accediese a la rebaja solicitada y que, «de conformidad con el precio rebajado» se exigiese a los adquirentes la regularización de las deudas sobre las que había informado el Departamento de Contabilidad. En cuanto a la pertinencia o no de otorgar al peticionario los títulos de propiedad, señalaba que se habían satisfecho las obligaciones de población, cercado y arreglo de las calles circundantes pero no las del cultivo de las tierras; y en lo referido a la exigencia de inversión de un capital por hectárea de 300 pesos el dictamen sostenía que

"[...] no se ha llenado si ha de entender tal obligación con rela. ción a la totalidad del terreno; y se habría llenado si el cómputo deberá hacerse refiriéndolo solamente a la superficie que tienen obligación de cultivar, vale decir, la cuarta parte de las extensiones acordadas". ${ }^{118}$

Si bien reconocía que la circunstancia de no haberse realizado todavía el cultivo podría constituir una falla en el otorgamiento del título de propiedad, la Dirección manifestaba que el hecho de haberse radicado en las chacras un capital en obras de riego de importancia que aseguraba la explotación de la tierra y el de la vigencia aún del plazo de dos años de que gozaban los adquirentes para satisfacer las obligaciones, además de la afirmación del recurrente de que necesitaban los títulos de propiedad para efectuar una operación hipotecaria, cuyo producto sería aplicado por entero a la continuación de los trabajos, colocaban a la repartición:

117 Ibidem.

118 D.E.R.-D.G.T. y C. Expediente núm. 10891-S-1911, folio 78. 
"[ [..] enfrente de un serio problema que afecta no solamente a los concesionarios sino también al prestigio y a la economía de la localidad.

En efecto, si esta Dirección extremara su rol fiscal y sostuviera con cierta dureza, que deben invertirse 300 pesos en cada una de las 2.500 hectáreas, prolongarse los canales de irrigación, termi. narse los cultivos etc. antes de otorgar el título de propiedad, es seguro que todo lo hecho quedaría malogrado, ya que en estas ma. terias la suspensión produce la ruina con todas las ingratas proyecciones antes señaladas. Planteada la cuestión así, es de considerar este punto esencial: las obras realizadas ya, minuciosamente espe. cificadas por el inspector Cornejo, ¿ofrecen al Estado una suficiente garantía con relación a la seguridad que el gobierno debe tener de que aquéllas serán terminadas y la totalidad de los terrenos colocados en situación definitiva de producir regular y pro. gresivamente?

Esta Dirección general no trepida en afirmar que ellas las ofrecen, pues las obras ejecutadas por los concesionarios - sobre todo las hidráulicas que, en este caso, constituyen la base fundamental de esa colonización - son de tal carácter que no pueden hacer abrigar ninguna duda sobre su eficacia, estabilidad, duración y arraigo definitivo al terreno, como también sobre los propósitos que animaron y animan a los concesionarios que las han realizado en tan corto tiempo". 119

Por último, y en referencia al hecho de que los trabajos realizados no estuviesen distribuidos por igual en todas las chacras «lo que obligaría dentro del régimen normal a otorgar la escritura de propiedad de las pocas chacras en las cuales están aglomeradas las obras hidráulicas», el informe concluía que tal criterio no era aplicable a este "caso verdaderamente excepcional porque los colonos que forman este núcleo son solidarios, trabajan en común y tienen una sola dirección y representación «juzgándose aceptable, por tanto, que «las obras realizadas se consideren debidas al esfuerzo

119 Ibidem, folios 78 y 79. 
común y por lo tanto que alcance a todos el beneficio de la escrituración de sus lotes» especificándose que, de aceptarse el otorgamiento de los títulos, éste debería hacerse previo pago total del valor de la tierra. ${ }^{120}$

En razón de que la inspección practicada había comprobado la construcción de importantes obras de irrigación «que funcionan perfectamente» además de la introducción de fuertes capitales «que han permitido a esos agricultores incorporar sus energías al adelanto de esa región» el poder ejecutivo sancionó un decreto del 29 de enero de 1912 por el cual se otorgaban los títulos de propiedad a nombre de los beneficiarios originales y se accedía a la rebaja del precio de la hectárea a 2'50 pesos. ${ }^{121}$

En síntesis, mediante un decreto de su amigo el presidente Sáenz Peña culminaban las exitosas gestiones emprendidas por el escritor las que habrían de caracterizarse durante todo su desarrollo, no sólo por la discrecional interpretación que de la letra de la ley harían los funcionarios intervinientes a fin de favorecer al solicitante, sino también por una asombrosa $y$ por momentos pasmosa celeridad del aparato administrativo-burocrático. ${ }^{122}$

No obstante, los títulos definitivos solicitados por Blasco Ibáñez y sus presuntos representados no fueron utilizados para cumplir con lo que aquél había manifestado en ocasión de su solicitud: «Mucho hemos hecho en poco tiempo, pero nos queda mucho más por hacer». Sus grandiosos proyectos de desarrollo de la produc-

120 Ibídem, folio 79.

121 Ibidem, folios 80 y81. La división contable de la Dirección de Tierras y Colonias confeccionó la liquidación de la deuda pendiente a los nuevos valores incluido el monto del primer vencimiento que aún no habia sido saldado, lo que totalizó la suma de $\$ \mathbf{6 . 2 5 0}$. Las tramitaciones culminaron el 15 de febrero cuando los títulos ya firmados por el poder ejecutivo fueron entregados a Blasco Ibáñez en su calidad de apoderado.

122 Cabe recordar que simultáneamente al otorgamiento de tierras en el valle del río Negro. Blasco Ibáñez había obtenido del gobierno de la provincia de Corrientes una concesión de 5.000 hectáreas en diez anualidades. En convenio suscrito obligaba al concesionario a vender la mitad de la superficie a agricultores españoles y a instalar maquinaria para la irrigación de las tierras. En caso de incumplimiento de las obligaciones, las tierras volverían a poder de la provincia. Cuenta Maida que: «Antes de que llegasen a Buenos Aires las familias españolas ya había negociado una sociedad anónima para explotar la colonia de Corrientes a los requisitos of 'ecidos al solicitar la concesión». (Maida: La colonización de Blasco lbáñez.... pág. 17). 
ción no tendrían, prácticamente, ni siquiera principio de concreción y sus afirmaciones de que «en el caso presente no se trata de una petición de títulos definitivos para vender luego los campos» serían bien pronto desmentidas por los hechos. En efecto: luego de la convocatoria a una asamblea extraordinaria de los accionistas de la Sociedad Cooperativa de Irrigación (junio de 1913), Blasco Ibáñez procedió a disolver la Sociedad y transfirió tierras y mejoras -incluidas las instalaciones del equipo de bombeo construidas sobre el lote fiscal núm. 316- al doctor José María Rosa (exministro de Hacienda de los presidentes Roca y Sáenz Peña) quien habría levantado una hipoteca de 30.000 pesos. La Sociedad Comercial J. M. Rosa e Hijos Limitada mantuvo prácticamente inactivas las chacras hasta la llegada del riego estatal en 1921. Procedió entonces a fraccionarlas y a ofrecerlas en venta a un precio que, con riego y desagües cuyo funcionamiento se garantizaba, oscilaba entre 1.300 y 1.700 pesos la hectárea según calidad de las tierras y forma de pago (al contado o en 100 cuotas mensuales). ${ }^{123}$

No había sido éste, seguramente, el final que imaginara Blasco Ibáñez para su proyecto. Pese a que debe darse fe a su propósito de desarrollar «una colonia de agricultores españoles dedicados al cultivo intensivo de huerta con regadío», no puede omitirse el hecho de que su intención última fue la de conseguir los títulos de propiedad a la espera del funcionamiento de las grandes obras hidráulicas cuya construcción ya había sido iniciada por el Estado. Por tanto y a la luz de sus objetivos reales, todo su proyecto adquiere necesariamente un mero carácter instrumental a ese objetivo prioritario. De ello habría de dar testimonio el mismo Blasco Ibáñez cuando en carta enviada a su amigo Patricio Piñeiro Sorondo en diciembre de 1910 , es decir, cuando aún no había principio de concreción a sus planes en el valle, manifestábale su preocupación por la posibilidad de que la obra del dique sobre el río Neuquén fuese

123 Ibidem, págs. 40 y 4q; D.E.R.-: Libro 295, folio 493; Toledo: Historia de la fundación.... páq. 26 «Revista del Ferrocarril Sud», Año I, núm. 3, septiembre 1925, y núm. 4, octubre 1925 y Rodríguez: El Alto Valle..., pág. 144. En 1919 la Cervecería Quilmes arrendó los lotes más aptos y mejor nivelados a la firma J. M. Rosa e Hijos para ensayar el cultivo de la cebada cervecera que pracasó pues el problema del riego aún no había sido resuelto. 
aprovechada únicamente en favor de las tierras de la altiplanicie y que, en consecuencia, la Cooperativa de Roca y los concesionarios del este debiesen arreglárselas «haciendo obras particulares». Pocos días después en otra carta al mismo destinatario reiterando aquella preocupación manifestaba:

«[...] $\sin$ perjuicio de cooperar a todos los proyectos que se hagan para la creación de un canal, tengo ya preparado todo lo necesario para establecer en mis tierras un riego provisional por medio de máquinas elevadoras que espero funcionen a fines del próxj. mo año». ${ }^{124}$

Aun cuando en principio algunos de ellos pudieran parecer meramente anecdóticos, los hechos que jalonaron la efímera vida de la Colonia Cervantes trascienden la esfera de lo doméstico y exhiben con particular contundencia aspectos que hacen a la propia naturaleza del Estado. Desde este plano es que deben explicarse, tanto la impunidad de que gozaban las élites privilegiadas en la utilización de procedimientos, algunos de ellos rayanos en lo ilegal a fin de conseguir sus objetivos, como la actuación de los funcionarios gubernamentales.

Si bien es cierto que Blasco Ibáñez se valió de todos los medios a su alcance para conseguir las tierras, se tratara de aquellos difícilmente impugnables en sí mismos como de otros calificables de delictivos ${ }^{125}$ (el empleo de verdades a medias cuando no del engaño, la morosidad o el incumplimiento de las reglamentaciones legales, la apelación a lo que hoy se denomina «tráfico de influencias», la utilización de testaferros, entre otros), lo principal es que para concretarlos debió contar necesariamente con la disposición y benevolencia del propio aparato del Estado.

Tal es el caso de la utilización de testaferros. La entrega de lotes agrícolas y pastoriles se hacía de acuerdo con lo establecido por

124 Boero de Izetta: Historia del valle..., pág. 18.

125 Sus acciones llevaron a algunos a sostener: «Fue un gran aventurero, su cultura le ha evitado hasta ahora agarrarse los dedos en la encrucijada del Código Penals. Diario «La Acción» del 5 de enero de 1925. Cit. en Maida: La colonización.... pág. 41. 
la ley núm. 4167. El decreto reglamentario del 8 de noviembre de 1906 había establecido claramente que «una sola persona o Sociedad no podrá adquirir, ni aun por interpósita persona sea directamente o por transferencias anteriores al pago total del precio, más de cuatro solares o dos lotes agrícolas». ${ }^{126}$ Las referencias de los funcionarios gubernamentales sobre la verdadera identidad de los concesionarios habrían de ser siempre vagas e imprecisas. Margueirat alude indistintamente a "varias familias agricultoras representadas por don Vicente Blasco Ibáñez», a «varios mandantes en Europa» o bien a «agricultores residentes en Europa». Aun cuando son contados los nombres de valencianos que han podido ser detectados en las fuentes, lo cierto es que de los hallados ninguno se corres. ponde con los de los beneficiarios originales de los lotes; el cúmulo de la información recogida permite aseverar que ni uno solo de ellos estuvo jamás en el valle. Como vimos el escritor hablaba de «mis tierras» para referirse a las de Colonia Cervantes y en Europa había manifestado su intención de establecerse en Argentina «donde he adquirido vastos territorios». Por lo demás, todos los pormenores que rodean el caso desde la puesta en marcha de su proyecto hasta el desenlace del mismo avalan la afirmación de que Blasco Ibáñez, al modo como lo harían otros importantes beneficiarios de esta legislación ad boc, recurrió al procedimiento de utilizar testaferros para eludir y burlar las leyes vigentes sobre concesiones de tierras públicas.

Otro de los aspectos destacables, aunque de ninguna manera privativo de las gestiones emprendidas por el escritor, radica en la comprobación de cuán eficaces y expeditivas podían llegar a ser las oficinas gubernamentales en sus resoluciones, según fuesen los interesados. En ese sentido, tal celeridad resulta no sólo remarcable en sí misma sino que lo es más aún cuando se repara en que algunos de los expedientes fueron tramitados en los días previos o subsiguientes a las fiestas navideñas, fechas por cierto nada propicias para concretar gestiones en instancias administrativo-burocráticas.

126 Ley 4167/1093; en: Anales de levislacion aroentina, complemento afios 1889-1919. Buenos Aires, 1954, págs. 593-595. 
Por otro lado, al repasar detenidamente los informes elaborados por los funcionarios intervinientes puede observarse no sólo que abundan las imprecisiones y contradicciones sino que, en casos, existe un deliberado ocultamiento de la realidad si con ello se favorecían las gestiones del solicitante. En tanto Cornejo, por un lado, no vaciló en utilizar como prueba y aval de sus constataciones documentación que le había proporcionado Blasco Ibáñez (planillas de presupuestos que le habían sido remitidas al escritor a su solicitud con fecha anterior a la de la inspección), como tampoco en aumentar de modo arbitrario los valores de los capitales introducidos para que alcanzasen a los exigidos por ley, por otro acentuaba el agobio económico a que aludía Blasco Ibáñez, si con ello aceleraba la tramitación en marcha.

Lo mismo habría de ocurrir con el tema del riego. Aun cuando en determinado momento Margueirat se vio llevado a decir que aquél no funcionaba a fin de apurar las tramitaciones que permitieran al solicitante obtener créditos, y Cornejo — quien como se vio tuvo una actitud más que benevolente para con el valencianono pudo menos que constatar que sólo había una hectárea regada con agua de tanque y que un sembrado de alfalfa no había logrado prosperar por falta de riego, en general la opinión de los funcionarios habría de ser unánimemente laudatoria. Así, basándose en el informe del inspector Cornejo, Margueirat afirmaba que los procedimientos utilizados para llevar el agua habían tenido un «éxito casi insuperable»; la Dirección General de Tierras y Colonias, por su lado, aseguraba que las obras ejecutadas eran de tal carácter «que no pueden hacer abrigar alguna duda sobre su eficacia, estabi. lidad, duración y arraigo definitivo al terrenow y que ellas constituían «de por sí una garantía de que serían llevadas a su término prolongando los canales de irrigación en la forma señalada en los planos a fin de que el riego alcance a todos los extremos de la Colonia». Por último, en los considerandos que avalaban la entrega de los títulos definitivos de propiedad solicitados por el escritor, el poder ejecutivo afirmaba que la inspección practicada acreditaba que la Sociedad Cooperativa de Irrigación Colonia Cervantes 
había construido «importantes obras de irrigación que funcionan perfectamente».

La experiencia «colonizadora» de Blasco Ibáñez concluyó, pues, con 2.500 hectáreas de las mejores tierras valletanas en manos de un solo propietario. Fueron transferidas al sector privado a razón de 2'50 pesos utilizando para ello el ardid de la constitución de una cooperativa de riego — que de tal sólo habría de tener el nombre-, y utilizando todo el poder del Estado, del Estado en concreto, personalizado en los funcionarios intervinientes, fueran éstos de carrera, como los de la Dirección de Tierras, o poli. ticos, como ministros y presidentes. Ello ocurría entre 1910 y 1913, cuando las grandes obras hidráulicas estaban ejecutándose. Las tierras permanecerían incultas durante más de una década y terminaron siendo fraccionadas a precios 600 veces superiores al que habían sido privatizadas.

\section{La Sociedad Cooperativa del Este}

En el mes de octubre de 1910, pocos días después de concedidas las tierras a Blasco Ibáñez, el poder ejecutivo sancionaba dos nuevos decretos. En el primero de ellos (6 de octubre) enunciaba que el doctor Santiago Amadeo Doléris había iniciado un expediente por el cual solicitaba para sí y en representación de las personas cuyos nombres indicaba, la concesión de varios lotes en la Colonia General Roca manifestando que era propósito de los peticionarios el destinarlos «a trabajos agrícolas y vitícolas de importancia, estableciendo al efecto viveros y viñedos que consulten las mejores experiencias realizadas en la localidad». Agregaba que, teniendo en cuenta «el renombre científico de algunos de los soli. citantes» así como la competencia que otros habían demostrado durante su estancia en el país lo que brindaba a la propuesta «todas las garantías exigibles», y que a pesar de que Doléris no había pre. sentado los poderes certificados de las personas que invocaba aduciendo «razones atendibles de urgencia para la adjudicación de 
esos lotes»-poderes cuya presentación la Dirección de Tierras y Colonias debería exigir en el término de sesenta días-, el presidente de la República decretaba la concesión en venta de unis 1.200 hectáreas (12 lotes; los números 387, 388, 389, 392, 393. 394, 403, 404, 405, 406, 407 y 408) a Doléris y sus representados. El grupo se hallaba integrado por Esteban Berlin, Roberto Schneider, P. Pacottet, F. Chabert, Santiago Delavigerie, Pedro y Santiago Amadeo Doléris.

Por el otro decreto, sancionado dos días después, se otorgaron 36 concesiones a 27 personas ( 9 de ellas recibían dos concesiones) que totalizaban aproximadamente unas 3.350 hectáreas (4 concesiones con un total de 300 hectáreas se encontraban fuera de lo que sería la zona de influencia de la Cooperativa del Este). Entre esos concesionarios se encontraban Patricio y Octavio Piñeiro Sorondo, José Cantutti (jefe de las Comisiones de Estudio e intendente general de irrigación en los valles del Negro y del Neuquén desde 1909), Benjamín y Eliseo Segura, Juan Bautista Evens, Pedro Vallèe, Luis Cipolletti, Pedro y Alberto Benegas, Felipe Bonoli (de activa participación en el fraccionamiento llevado a cabo en la segunda mitad de la década de 1920 por la CIAC en Villa Regina) y otros. Residentes en su gran mayoría en la ciudad de Buenos Aires, recibieron como mínimo superficies de 100 hectáreas cada uno, aunque hubo 2 con 150 hectáreas y 6 con 200 hectáreas. ${ }^{127}$

La gran mayoría de los beneficiados con ambas disposiciones integrarían la Sociedad Cooperativa del Este. Esta fue conocida también como Cooperativa Francesa en virtud que sus principales accionistas entre otros los doctores Doléris y Evens, eran de esa nacionalidad. La documentación analizada muestra que no sólo se trataba de ciudadanos de origen francés sino que, en su mayoría continuaban residiendo en Francia. Tales los casos del propio S. A. Doléris, de Estefano Merlin, médico como el anterior y domiciliado en la ciudad de Provins, Departamento del Seine Marne del país galo, del doctor Enrique P. Vallée, profesor de una escuela de Veterinaria en Francia, del ingeniero Roberto Schnei-

127 Boletín Oficial, 14 de octubre de 1910.

Tomo XLVII 
der $\mathrm{y}$ de Santiago Delavigerie, radicados ambos en la capital francesa. ${ }^{128}$

Siguiendo el modelo de la Sociedad Cooperativa de Irrigación de la Colonia Roca, los concesionarios de los decretos del 6 y 8 de octubre de 1910 se comprometían a constituir una sociedad cooperativa construyendo los canales necesarios e instalando las bombas necesarias para la elevación mecánica del agua, para cuyo emplazamiento los propulsores de la sociedad cooperativa habían solicitado la reserva de la chacra núm. 367. Para ello se instaló una usina con dos bombas hidráulicas que podrían elevar el volumen de agua suficiente para el riego de las 6.000 hectáreas comprendidas en el proyecto. Al parecer la puesta en marcha de estas obras fue bastante más lenta que en el caso de las emprendidas por Blasco Ibáñez. Esto sería así por cuanto la sociedad se habría constituido en 1911, sus estatutos resultarían aprobados en enero de 1912 y en junio de 1915 las obras básicas estaban aún en cons. trucción. Fue entonces cuando crecientes extraordinarias del río Negro (aún no se habían completado la construcción del dique y el canal aliviador) causaron la completa destrucción de las instalaciones al minar la barranca sobre la que se hallaban ubicadas. ${ }^{129}$

En su informe sobre la zona en un tiempo comprendida por la Sociedad Cooperativa del Este, el capitán de fragata Justino Riobó expresaba, en 1920:

123 Mahilet: El Alto Valle..., pág. 36; Rodríguez: El Alto Valle..., pág. 140 y D.E.R.-D.G.T. y C.: Inspección General de Tierras. Territorio del Rio Negra, Informes afios 1924 al 29. Libro 428, folios $344,345,346,351,353,379,380$ ). Idéntica información sobre Doléris sería proporcionada por Pedro Girotti uno de sus arrendatarios quien manifestó, con motivo de la inspección efectuada en la chacra núm. 387, que ocupaba la misma desde abril de 1923 por contrato con el Sr. Luis Burat apoderado del Sr. Santiago Amadeo Doléris, aquien vive en París». (Ibidem, folio 331). Por su parte el profesor Pablo Pacottet, también ciudadano francés, se encontraba circunstancialmente en el país en virtud de un contrato firmado con el Gobierno para prestar servicios en el Ministerio de Agricultura argentino durante cinco años. (Boletín Oficial, 22-2-1912).

129 Molins: El Alto Valle..., pág. 85; D.E.R.-D.G.T. y C. Expediente 6602-V. 1910, folio 13 vta.; Mahilet: El Alto Valle..., pág. 36 y Maida, Esther L.: Historia del origen y evolución del origen y evolución del riego en el Alto Valle (mecanograflado), General Roca, diciembre de 1970, págs. 30 y 31. 
"[...] una creciente del Río Negro destruyó la bocatoma en cons. trucción y esta Cooperativa fracasó antes de poder regarm. ${ }^{130}$

Por su parte y sobre la base de testimonios orales Maida dice en relación con el final de esta entidad que

(En momentos difíciles, presas de frustración, los obreros de la mampostería, afectados a la obra de la toma de agua, llegaron a arrojar a un brazo del río implementos de trabajo, carretillas y barricas llenas de herramientas $[\ldots]$.

No había dinero para continuar (la obra de riego,) y, al fundirse la compañía Francesa, se produjo el desbande de los que trabajaban en esas propiedades». ${ }^{131}$

Al describir la situación del pueblo Ingeniero Huergo - ubicado en el centro de lo que habría sido el área regada por la Sociedad Cooperativa del Este- y su zona de influencia expresaba Riobó:

"Actualmente, tiene Ingeniero Huergo, 22 solares poblados les decir, con viviendas construidas), de los cuales hay sólo siete habitados, encontrándose el resto completamente abandonados. Las quintas se encuentran cercadas y pobladas casi todas, pero nadie reside en ellas ni las cultiva.

De este modo resulta, que de más o menos treinta y seis casas que constituyen el pueblo en su planta urbana y quintas, sólo hay siete casas habitadas.

Esto obedece a que, la mayoría de las personas que ocuparon y solicitaron tierras en este pueblo, e introdujeron las mejoras que esta Comisión ha encontrado, lo hicieron en la inteligencia de tener agua de riego en plazo breve, mediante las obras que en aquella época realizaba la Cooperativa del Este sociedad fundada con el propósito de regar la zona Este de la Colonia General Roca [...]. Én esta circunstancia, aquellos pobladores no tuvieron más remedio,

130 D.E.R.-D.G.T. y C.: Libro 294, folio 337.

131 Maida, Esther L.: Historia del origen.... pág. 31. 
que abandonar momentáneamente sus solares y quintas para fr a trabajar en la zona regada.

De este modo, puede decirse, que el pueblo Ingeniero Huergo actualmente existe en la mente de los que allí tienen mejoras. los cuales esperan ansiosamente el agua que próximamente les dará el canal del Gobierno, para volver a radicarse definitivamente en él.

Como lo que pasa con Ingeniero Huergo ocurre también con los lotes agrícolas de la Colonia Roca en la zona de influencia de este pueblo, el comercio es todavía escaso o nulo". ${ }^{132}$

Sintetizando el final de la Sociedad Cooperativa del Este en la frase de Riobó de que aquélla «fracasó antes de poder regar», resta analizar qué sucedió con las tierras públicas concedidas de acuerdo con las disposiciones legales vigentes que obligaban a los concesionarios a cercar, poblar, desmontar, cultivar, constituir sociedades cooperativas para el riego de sus lotes, invertir como mínimo 300 pesos por hectárea, etc.

Por la extensión de la superficie involucrada, por las peculiaridades de su desarrollo y desenlace y por el hecho de que esto último habría de reiterarse en buena parte de las otorgadas por el decreto del 8 de octubre de 1910, el caso de las concesiones al grupo en. cabezado por el doctor Santiago Amadeo Doléris resulta altamente ilustrativo.

Santiago Amadeo Doléris era médico, miembro de la Academia de Medicina de París. ${ }^{133}$ Según su relato, el 6 de junio de 1910, partió desde Plaza Constitución «en vagón especial reservado» con el objeto de efectuar una visita a Río Negro y Neuquén, siendo despedido en la estación por el presidente del Consejo Municipal de la ciudad de Buenos Aires, J. Guerrico (integrante de la Cooperativa de General Roca, como se vio) y el gerente general de la Compañía del Sud. Doléris fue acompañado en su viaje por Pedro Benegas, gran propietario y fuerte bodeguero mendocino, y el ingeniero Coleman quien llegaría a ser gerente generai del Ferrocarril

132 D.E.R.-D.G.T. y C.: Libro 294, folio 337.

133 D.E.R.-D.G.T. y C.: Libro 428, folio 379. 
del Sud comisionado en la oportunidad para actuar como guía. Durante el detenido recorrido de varias semanas por la región, «el trío de excursionistas», al decir de Doléris, tuvo a su exclusiva disposición un tren compuesto únicamente de tres vagones: uno destinado a los invitados, Doléris y Benegas, otro para el anfitrión, el ingeniero Coleman, y un furgón. ${ }^{134}$

Acordadas las concesiones y luego de un período no precisado de estancia en la Argentina, Doléris volvió a Francia. Desde Lembeye (Bajos Pirineos) había de otorgar un poder especial a Luis Burat, domiciliado en la región, encargándolo de la administración de los lotes. Hacia 1920 y en oportunidad de la inspección ya mencionada del capitán de fragata Justino Riobó, éste manifestaba en relación a estas tierras:

"[...] hemos de referirnos ahora a un presunto acaparamiento de 1.000 hectáreas en las proximidades de Ingeniero Huergo, acerca del cual existe la posibilidad de evitarlo, puesto que esa tierra sólo se encuentra afectada a concesiones en vigencia cuyas exigencias no han sido llenadas en la mayoría de los casos.

Durante la inspección de la Colonia, dos personas radicadas desde hace varios años en ella - los señores David Martínez y José María Sánchez - denunciaron ante esta Comisión, que los lotes 387, 388. $389,394,403,404,405,406,407$ y 408 son considerados en la región como de propiedad del Señor Santiago Amadeo Doléris, por ser esta persona la que introdujo las mejoras que en ellos existen y la única que ha ejercido actos de propiedad sobre esos lotes.

Estas denuncias, cuyas actas firmadas por los denunciantes obran en poder de esta Comisión para ser agregadas a los expedientes respectivos, bastan a nuestro juicio, para establecer una presunción de acaparamiento que podría determinar por sí sola la caducidad

134 Las impresiones que la región provocó en Doléris se reflejaron en los exultantes párrafos que éste había de dedicar a la misma en su libro: Le Nile Aroentin: Etude Economique et agricole sur les Régions du sud argentin. Editado en París. en 1912 (20\& págs.), apareció con una dedicatoria del autor a «A S.E.M. Roque Sáenz Peña, Président de la République Argentine ardent promoteur de la colonisation du Sud».

Tomo XLVII 
de estas concesiones, sino fuera que ya sería aconsejable esta medida por la falta de cumplimiento a las condiciones exigidas por la ley respectivan.. 135

Mediante la inspección realizada lote por lote, la Comisión verificó que ninguno se encontraba ocupado ni habitado; cuatro contaban con vivienda mereciendo solamente una de ellas el calificativo de buena, las demás carecían de puertas y aun de techos y, en casos, sólo habíanse levantado los cimientos. Tampoco registrábase cultivo alguno. El alambrado perimetral, unas pocas hectáreas desmontadas y emparejadas y algunos metros de acequias constituían todo el trabajo cultural concretado en una década. En síntesis, a comienzos de 1920, los lotes adjudicados a Doléris y sus representados se encontraban en completo abandono. ${ }^{136}$

El informe general elaborado por Riobó en el que éste da cuenta de la denuncia del acaparamiento está fechado el 30 de julio de 1920. Menos de dos meses después de la inspección y, a diez años de la disposición que le otorgaba plazo de sesenta días para acreditar legalmente las personas invocadas Doléris, alegando aún carácter de «mandatario verbal», gestionó ante un mismo notario de París, y el mismo día, los poderes por los cuales sus mandantes designaban administrador a Luis Burat a fin de que éste los representase ante el gobierno argentino y ejecutase todas las acciones y gestiones que fuesen necesarias en relación con sus concesiones, ${ }^{137} \mathrm{~A}$ dichos poderes seguirían otros tramitados cuatro años después en el consulado argentino de París, con la asistencia

135 D.E.R.-D.G.T. y C.: Libro 295, folios $402-403$

136 D.E.R.-D.G.T. y C.: Libro 295, folios 511-512 y 518-519.

137 El Inspector Capdevila - de la Dirección de Tierras y Colonias-- asevera que fue confeccionada documentación similar para todas las concesiones comprendidas en el decreto del caso, excepto la correspondiente al lote núm. 393 cuyo beneficiario era Pablo Pacottet (D.E.R.-D.G.T. y r.: Libro 428, folios 395-396). El hecho de que en ésta haya sido designado un apoderado distinto de Burat quien elaboró, además, un contrato de arrendamiento con cláusulas más liberales de las que confeccionara aquél; y la circunstancia de que sea precisamente el único lote que no aparece en la Planimetría de 1935 a nombre de la Sociedad Anónima La Ađricola e Industrial de la Argentina o de Doléris. lleva a concluir que. si bien Pacottet integró el grupo original de solicitantes de 1910 arbitró sus intereses con relativa autonomía. 
de idénticos testigos, por los que se comisionaba a Burat que solicitase los títulos de propiedad.

Transcurridos catorce años de otorgadas las concesiones, las msmas habrían de ser objeto de nuevas inspecciones ordenadas por la Dirección de Tierras y Colonias. Los informes que en esta oportunidad elaboró A. Capdevila ponen en evidencia que Doléris había logrado no sólo mantener el control y usufructo de los lotes que detentaba a título personal sino que, incluso, había ampliado su número a once a despecho de que éstos figuraran empadronados por la Intendencia de Riego a nombre de sus concesionarios originales. De hecho había sido Doléris quien, siempre a través de Burat, contratara con terceros los trabajos a llevarse a cabo en las chacras en calidad de mandatario de los beneficiarios primitivos, situación que explicitó con claridad Capdevila al informar que las tales concesiones eran conocidas en la zona como parte de «las chacras del Sr. Doléris». La Planimetría confeccionada en el año 1935, por último, habría de registrar 8 de los lotes a nombre de la Sociedad Anónima La Agrícola e Industrial de la Argentina, y los otros tres como propiedad de Doléris. ${ }^{138}$

Particular atención merece, de otra parte, la rica información que brindan los funcionarios oficiales en especial la referida a la contratación de arrendatarios como el procedimiento más comúnmente empleado por los adjudicatarios de tierras para dar cumplimiento a las obligaciones que les imponía la legislación. A partir de los informes contenidos en el Libro 428 puede observarse que Doléris y otros concesionarios, conocida la inminente llegada del riego - los secundarios VI y VII que sirven la zona fueron habilitados en marzo de 1921 - se apresuraron por hacer levantar viviendas en las «chacras» con el objeto de arrendarlas, aun cuande a la fecha de acordarse este tipo de contratos (entre abril y agosto

138 D.E.R.-D.G.T. y C.: Libro 428, folio 370 y M.O.P. D.G.I. Inspección General Zona Sud. Obras de Río Negro Superior. VII a XVIII de Riego. Planimetría general S-1639, Buenos Aires, 1931. Aun cuando no se pueda demostrar de modo absolutamente fehaciente, dados los antecedentes expuestos, cabe pensar que con la constitución de la Sociedad Anónima Doléris legalizaba la propiedad de las tierras. 
de 1923) todavía figurase en algunos casos la construcción de las mismas entre los compromisos que asumía Doléris. ${ }^{139}$

Para entonces habíase dado cumplimiento, de modo parcial, a la obligación de construir viviendas puesto que éstas no llenaban los requisitos en cuanto al tipo de edificación a realizar. Ocho de los lotes se encontraban arrendados mientras los otros tres lo habían estado anteriormente correspondiendo a los arrendatarios la adición de algunas mejoras suplementarias, la siembra de un total de 464 hectáreas de alfalfa, el desmonte de algunas decenas más (sobre un total aproximado de 1.080 hectáreas) y la implantación de un número considerable de cortinas protectoras de álamos y de algunos frutales. ${ }^{140}$ Según manifestarían en su declaración Isaac y José Locev, ellos habían sido «los primeros ocupantes de dichas tierras» sembrando 25 hectáreas en los lotes números 388-389-392. 404-407 y 408 (afirmación que los informes confirman) mediante convenios oportunamente concertados con Luis Burat. ${ }^{141}$

El tiempo de duración de los contratos no era uniforme y oscilaba entre 3 y 5 años que era lo habitual en la zona. Pero lo remar-

139 D.E.R.-D.G.T. y C.: Libro 428, folios 332-398.

140 Este método, que hemos calificado de puesta en producción terrateniente de las tierras en tanto se basa en lo fundamental en el trabajo rendido por «medianeros», venía siendo empleado por Doléris desde comienzos de la década anterior en la Colonia Picasa. Esta se constituyó rodeando la actual localidad de Cinco Saltos, mediante el fraccionamiento y venta de una superficie aproximada de 3.000 hectáreas que habían sido adquiridas por la Compañía de Tierras del Sud. En el Censo Agrícola de 1918-1919, con 186 hectáreas de las cuales 92 ha. se encontraban sembradas con alfalfa, 23 con hortalizas y 6'5 has. implantadas con viñas. Ministerio de Obras Públicas. Dirección General de Irrigación. Intendencia de Riego del Río Negro Superior. Colonia Picasa: Censo Agrícola del período 1918-1919. Tomado el 30 de septiembre de 1918.

Algunos años más tarde Doléris aplicaría en esas tierras la forma de realización de la renta terrateniente que otorga al Alto Valle su especificidad: la del fraccionamiento y venta. Y para hacer del caso uno de los ejemplos más representativos de las características principales del desarrollo histórico del Valle en las primeras décadas de este siglo, ello tuvo lugar mediante la aplicación de una línea de crédito puesta en práctica por el gobierno radical a través del Banco Hipotecario Nacional. En el informe de su visita de inspección al Alto Valle en 1928, el vicepresidente del Banco Hipotecario Nacional Alfredo Goti menciona entre otros fraccionamientos el de la Colonia Doléris que, kubicada cerca de la estación Ferri fue fraccionada y rematada el año ppdo., con préstamos de colonización». Goti, Alfredo. Vicepresidente del Banco Hipotecario Nacional: La colonización en el valle Superior del Rio Negro, en «Revista del Ferrocarril del Sud», números 39 y 40. Buenos Aires, septiembre y octubre de 1928.

141 D.E.R.-D.G.T. y C.: Libro 428, folio 392. 
cable del caso radica en que no sólo determinábase un plazo perentorio para finalizar la implantación de los cultivos de alfalfa, sino que se especificaban incluso los recaudos que tomaba el concesionario si sus locatarios no cumplían con lo acordado al respecto. Según el art. 8." del contrato celebrado con Girotti, por ejemplo, quedaba expresamente aclarado que aquél quedaría nulo en caso que las 25 hectáreas no estuviesen sembradas en la fecha indicada abonándosele al arrendatario, en tal caso, el $50 \%$ del valor de los trabajos que hubiere realizado. La existencia de cláusula semejante y el hecho de que los contratos con los arrendatarios fuesen acordados mayoritariamente entre abril y agosto de 1923 lleva a pensar que, conversaciones y relaciones mediante, Doléris haya obtenido algún plazo para dar cumplimiento a las obligaciones de la ley.

La circunstancia de que durante catorce años esas tierras permaneciesen prácticamente incultas, el tipo de mejoras introducidas -las mínimas para cumplir con la ley-y las consideraciones que las mismas merecieran de los funcionarios gubernamentales por no mencionar sino los hechos más evidentes, llevan a recordar de inmediato los proyectos enunciados por Doléris y que fueran retomados, a su vez, por el poder ejecutivo en los considerandos del decreto de concesión. En ese sentido, la declamada intención de destinar los lotes a trabajos agrícolas y vitícolas de importancia estableciendo viveros y viñedos acordes a las mejores experiencias realizadas en la localidad, contrasta drásticamente con la situación que describen las inspecciones mencionadas.

Si pasado tanto tiempo Doléris se decidió a realizar las tramitaciones necesarias para dar cumplimiento a las exigencias de la ley (cumplimiento que, como se vio, no derivaría de la inversión de capital sino del trabajo de sus arrendatarios), resulta válido pensar que alguna garantía o seguridad se le habría ofrecido desde las esferas decisorias sobre el éxito final que tendrían sus gestiones. Sobre la magnitud de éste puede tenerse una idea aproximada si se recuerda que de acuerdo a las condiciones de la concesión y de la constitución de la Cooperativa el precio por hectárea era de 2'50 pesos, en tanto que las tierras regadas sin sistematizar se ven- 
dían por entonces a no menos de 600 pesos la hectárea y hasta $1.500 .{ }^{142}$

Hacia el fin de la segunda década de este siglo, ya no quedaban «chacras del gobierno salvo uno que otro retazo». ${ }^{143} \mathrm{El}$ control de las inundaciones y el riego eran ya una realidad cuando Doléris logró retener casi 1.100 hectáreas de alto valor unitario pese al manifiesto incumplimiento de las obligaciones de la ley, lo que permite deducir que sus vinculaciones con el poder eran lo suficientemente fuertes como para evitar que otros miembros de la élite pudiesen disputarle esas tierras bajo la fachada de exigir un estricto cumplimiento de las disposiciones legales. Nada mejor para sintetizar algunos de los aspectos principales de este caso que transcribir el Informe que, a modo de conclusión, elevó Capdevila en 1924:

"Como se comprueba por los respectivos informes sobre el estado actual de la tierra, ninguno de los concesionarios de las citadas ejerce o ha ejercido la ocupación personal, al contrario, los actuales ocupantes además de trabajarlas pagan el arrendamiento en diver. sas formas al Sr. Doléris.

A pesar de ser concesiones del año 1910, recién a los doce años o sea en 1922, se ha empezado a dar cumplimiento a las obliga. ciones de ley, y a pesar del apuro de estos últimos tiempos, en muchas no se ha cumplido aún el requisito de la plantación de árboles.

La introducción de las mejoras y cultivos data recién de 1922 como se comprueba por los contratos de arrendamiento y por la declaración de los Señores Isaac y José Locev, primeros ocupan. tes de esas tierras.

Por otra parte, queda comprobado el acaparamiento por los datos siguientes:

Que casi todas las mejoras son del mismo tipo y que datan más o menos de la misma fecha. Por los contratos de arrendamiento y demás documentos en los que figura siempre el Sr. Luis Burat, como apoderado del Sr. Santiago Amadeo Doléris. Por los poderes

142 Goti: La colonizacion...

143 Molins: El Alto Valle..., pág. 88. 
otorgados en París el 25 de septiembre de 1920) en los cuales è Sr. Santiago Amadeo Doléris en representación verbal de los demás concesionarios dio poder al Sr. Luis Burat, y en las legali. zaciones se ve que han sido hechas en una misma fecha lo que demuestra que ha sido una misma persona la encargada del trámite. Posteriormente los concesionarios, cada uno por su parte, por ante el Consulado Argentino en París, con fecha 5 de marzo de 1924, dan un nuevo poder al Sr. L,uis Burat para que gestione los títulos de propiedad de las chacras, y llama la atención que todos lo hagan en un mismo día y con los mismos testigos. Por último esas tierras se conocen en esta Colonia con los nombres de 'Acaparamiento de Doléris' o de 'Colonia Francesa'”. ${ }^{144}$

En tanto, de las 3.050 hectáreas otorgadas al otro grupo (32 concesiones), 1.750 hectáreas (18 concesiones) habían pasado ya a dominio privado en oportunidad de la inspección llevada a cabo por Riobó en 1920. En tal situación se hallaban, entre otras, las originalmente concedidas a Antonio Devoto; Octavio Piñeiro Sorondo; Patricio Piñeiro Sorondo; Lorenzo Perellano (todas de 200 has.); Luis Luiggi (150 has.) y José Cantutti (100 has.). Pese a que las obligaciones de la concesión no habían sido cumplidas sino muy parcialmente, y apoyándose - como ya se vio en casos anteriores- en la benevolencia y aun en la connivencia dolosa de los funcionarios estatales, los interesados obtuvieron rápidamente los títulos de propiedad previa reducción del precio ya que pudieron demostrar haber suscripto acciones de la cooperativa del Este. ${ }^{145}$

La mencionada inspección del capitán de fragata Riobó (febrero y marzo de 1920), encontrará las 14 concesiones restantes ( 1.300 hectáreas) en una situación de completo abandono, con una sola de las chacras ocupadas por un encargado; mínimas mejoras (alambradas perimetrales en la mayoría y viviendas en 5 de las

144 D.E.R.-D.G.T. y C.: Libro 428, folios 395-396; subrayado en el original

145 D.E.R.-D.G.T. y C.: Libro 295, folios 458, 476, 499, 500, 504, 505, 507. 517. 524 y 525. M.O.P. D. G. I. Inspección Zona Sud. Río Negro Superior. III a VII Zonas. Planimetria General S- 2803. Buenos Aires, enero de 1935. 
chacras, todo en regular o mal estado) construidas en 1915; exiguas extensiones desmontadas y niveladas en sólo algunas; ausencia total de cultivos. Las inspecciones practicadas en los meses de octubre a diciembre de 1924 por el auxiliar de tierras Arturo Capdevila habrian de registrar un panorama significativamente modificado. Las chacras 353 y 354, concedidas originalmente a Enrique Madero y M. Pinedo habían salido del dominio del Estado. El primero - perteneciente, como el segundo, a una de las «tradicionales» familias de Buenos Aires- había logrado, pese al evidente incumplimiento de las condiciones de la concesión, la escrituración de ambos lotes. Capdevila constata que los lotes restantes habían sido ocupados entre 1921 y 1923 (cabe recordar que el servicio de riego dependiente del sistema estatal fue habilitado en esta zona en marzo de 1921) y que se habían introducido mejoras -en distinto grado- en alambradas y viviendas; que prácticamente la totalidad de la superficie se hallaba desmontada y nivelada; se habían construido las tomas de agua de riego así como los canales y acequias interiores e implantado cultivos de alfalfa en alrededor del $90 \%$ de la superficie de las chacras, además de haberse efectuado plantaciones de árboles frutales, viñas y alamedas. ${ }^{146}$

También en este caso, la llegada del riego y las perspectivas de la inmediata valorización de las tierras que ello suponía impulsó a estos concesionarios a cumplir con la contratación de arrendatarios, al modo de Doléris, otros apelaron a formas alternativas; bien la de otorgar a uno o más ocupantes un permiso provisional de usufructo de la tierra a condición de obtener todas las mejoras que los mismos hubieran introducido bien la firma de los denominados «contratos de compra-venta». Por éstos, el concesionario vendía al ocupante parte o la totalidad del lote cuya escritura entregaría una vez que la obtuviese, a su vez, del Gobierno a cambio del compromiso del comprador de «efectuar todos los trabajos y a llenar las obligaciones establecidas en el título provisorio como necesarios para obtener el título definitivo». En algunos casos

146 D.E.R.-D.G.T. y C.: Libro 295, folios 458, 476, 499-500, 504-505, 507, 517 y 424-525 y Libro 428, folios 267, 281, 289, 290, 300, 294-297, 408-431, 445-454, 458-461 у $468-488$. 
corrían por cuenta del ocupante no sólo las erogaciones necesarias para dar cumplimiento a las obligaciones de poblamiento, sino incluso las derivadas de la suscripción de las acciones para integrar los fondos de la cooperativa de riego, correspondiente a la extensión que recibía en venta. ${ }^{147}$

Realizar una evaluación de la experiencia de la Cooperativa del Este obliga a reiterar conceptualizaciones ya efectuadas en relación con los otros casos estudiados: venta a minorías privilegiadas de miles de hectáreas de tierras públicas a precio vil a condición de la ejecución de obras y cultivos jamas realizados; consecuente configuración de una estructura de la propiedad de la tierra concentrada, altamente monopólica; utilización de múltiples artimañas para burlar la ley incluso el empleo de testaferros (Doléris); tierras que permanecen incultas por más de una década aun después de ser beneficiadas por las obras solventadas con recursos del Estado, a la espera de que la expansión de las actividades económicas y la demanda valorizasen el monopolio de la propiedad del suelo en la medida exigida por sus detentadores para desprenderse de él.

\section{Conclusiones}

¿Cuáles fueron los resultados de la legislación arbitrada entre 1907 y 1910 para las tierras de la región?

Tanto la Cooperativa Cervantes como las del Este y ChoeleChoel no llegaron a regar; las 2.500 hectáreas adjudicadas a Blasco Ibáñez - burlando mediante «el tan socorrido sistema de testaferros» la disposición legal que limitaba a dos lotes de 100 hectáreas la cantidad que podía concederse por persona- pasaron a manos de un solo propietario permaneciendo prácticamente incultas hasta después que hubo llegado a ellas el riego a través del sistema construido por el Estado. Las entregadas a Doléris y los demás integrantes de la Cooperativa del Este —entidad «que fracasó antes de poder regar-», quedaron abandonadas por años pasando final-

147 Ibídem. 
mente a propiedad de aquél y algunos otros privilegiados aun cuando las obligaciones establecidas por la legislación hubieran sido tardía y parcialmente cumplimentadas, cuando no directamente insatisfechas. Destino similar sufrieron las tierras bajo influencia de la Sociedad Cooperativa de Choele Choel, que, para 1920, se hallaban completamente incultas. En tanto, la única de las entidades cooperativas que estuvo en condiciones de exhibir la realización de obras que efectivamente prestaron servicio contó con un régimen preferencial que concluiría con el traspaso de aquéllas al Estado, cuando el problema de la salinización de los suelos por falta de drenajes amenazaba con desvalorizar las propiedades.

Al fundamentar la sanción del decreto de 1907 el gobierno consideraba que debido al alto costo del trabajo de desmonte y puesta en producción de las tierras valletanas

"[... han quedado sin cultivar las chacras cuyos concesionarios han carecido de recursos, notándose en plena prosperidad las obte. nidas por colonos que han llevado alli el capital requerido, por lo cual debe aprovechar el $P$. E. la experiencia hecha y modilicar la reglamentación en esas colonias de acuerdo con sus enseñanzas, distribuyendo los lotes entre personas que se encuentren en condiciones de aplicarlas al cultivo intensivo de que son susceptibles, con el propósito de estimular el aumento de la producción nacional. ${ }^{148}$

Evaluar los resultados de la legislación que promovió la constitución de cooperativas de regantes a la luz de sus objetivos lleva, pues, necesariamente, a reconocer su fracaso.

Excluidos explícitamente «los colonos desprovistos de capital», el resultado de su aplicación, desde el punto de vista de la distribución de la tierra, no pudo haber sido sino el que fue, es decir, el de consolidar una estructura de la propiedad fundiaria altamente concentrada. Desde esta perspectiva pueden catalogarse las cooperativas de riego como un poderoso instrumento al

148 Decreto reglamentando.... pág. 3.4. 
servicio de una apropiación latifundista. Originadas en una legislación de intencionalidad progresista que legitimaba sus medidas excepcionales en razones de interés público («con el propósito de estimular el aumento de la producción nacional»), estas cooperativas constituyeron de hecho y de derecho vehículos a través de los cuales minorías privilegiadas se reservaban las tierras de la región; no sólo quedaron marginados expresamente los agricultores sin recursos, sino que terminaron siendo también excluidos otros interesados, que pese a poseerlos, no gozaban del necesario favor oficial. ${ }^{149}$ Por ello y en la medida que los gestores y beneficiarios directos de tales entidades se hallaban vinculados estrechamente al poder político y a los intereses económicos dominantes, cabe afirmar que, en esencia, aquéllas favorecieron una distribución elitista de la tierra.

Al tiempo que el ingeniero César Cipoletti daba fin al estudio que le encomendara el gobierno nacional tendente a encontrar una solución integral al problema del agua (control de las inundaciones: e irrigación) y tenía lugar la llegada del ferrocarril, se afianzaba el convencimiento de que la productividad del suelo como elemento cualitativamente mensurable (y por ende su valorización) dependía por entero del riego. Las nuevas circunstancias resultaban prometedoras para aquellos que consiguiesen hacerse de las tierras fiscales aún existentes y en ese contexto es como debe ser interpretada la derogación de las reglamentaciones que hasta entonces habían regido la enajenación de lotes agrícolas y la promulgación de un novedoso estatuto legal que, lejos de facilitar su adquisición por parte de agricultores sin recursos dejaba aquéllos real y explícita-

149 Esa fue la suerte que corrió, por ejemplo, la presentación de un grupo de 10 personas quienes a escasos 20 días de la promulgación del decreto del 24 de septiembre de 1907 constituyeron una sociedad bajo el nombre de «Cooperativa de Irrigación en la Colonia General Rocax y se presentaron ante el ministerio de Agricultura solicitando 1.000 hectáreas. Margueirat desestimó la presentación expresando: «La presente solicitud se encuadra dentro de las disposiciones del Decreto que reglamenta las condiciones de venta de los lotes en la Colonia Roca, no obstante creo deber decir que dada la poca capacidad del actual canal que lleva muy poco agua cuya prolongación sería imposible sin ensanchar su cauce, estimo conveniente que toda la concesión se acuerde a aquellos que formen parte de la sociedad que dió motivo al Decreto mencionado [...]». D.E.R.-D.G.T. y C. Expediente núm. 7328S-1907. 
mente «fuera del alcance de colonos agrícolas desprovistos de capital».

Ahora bien, ¿qué elementos novedosos contiene la nueva legislación en relación con la que hasta entonces se había aplicado paar distribuir las tierras de la región?

En primer lugar, se trata de una legislación que reconoce como su origen expreso el interés y las consecuentes gestiones llevadas a cabo por integrantes de un grupo socialmente reducido con la finalidad de obtener la concesión de las que por entonces eran las últimas tierras fiscales disponibles en la región; en ese sentido se trata de una legislación ad boc manifiestamente para dichos particulares y por su iniciativa. En todos los casos, la medida legal se halla precedida por peticiones elevadas por aquéllos ante el ministerio de Agricultura, que concluyen en la sanción de los respectivos decretos del ejecutivo nacional. Por éstos, a los peticionarios les era explícitamente reconocida la prioridad en la adjudicación de las tierras y recibían éstas en condiciones sumamente ventajosas, al tiempo que se arbitraba la caducidad de concesiones otorgadas con anterioridad y la expulsión de los intrusos. La explícita discriminación que ello entraña, a diferencia de la que de modo más o menos evidente subyace en todas las formas a que recurriera con anterioridad el Estado para enajenar la tierra pública (remates de enormes superficies publicitados y realizados en Buenos Aires, concesiones de dilatadas extensiones a las denominadas compañías colonizadoras, empréstitos contraídos por el Estado pagaderos en tierras que estipulaban la obligación de suscribir un número determinado de bonos, etc., mecanismos todos que excluían de hecho al «pobrerío») se fundaban ahora en supuestas razones de conveniencia $o$ interés general apelándose desde el poder a un consenso a partir de cuya consecución pretendían legitimar intereses minoritarios.

El decreto de 1907, que sirvió de modelo a los posteriores, comenzaba por explicitar el hecho de la cuantía de los gastos que requerían esa clase de tierras para entrar en producción y aludía luego a la experiencia (supuestamente ya realizada) que demostraba la prosperidad obtenida por los «colonos» que habían contado con 
recursos suficientes en contraposición a aquellos que habían carecido de los mismos. Tales aseveraciones concluían en la afirmación explícita de que la posesión de capital y la declamada intención de invertir éste en la tierra constituían los elementos definitorios a partir de los cuales se legitimarían las futuras solicitudes de lotes quedando éstos de hecho y de derecho «fuera del alcance de colonos agricultores desprovistos de capital». La lógica de la conclusión en la que derivaba razonamiento semejante - expuesto a modo de silogismo - quedaba no obstante invalidada en sí misma en tanto provenía del encadenamiento de dos afirmaciones previas de las cuales, aquella que aseveraba la prosperidad obtenida por los «colonos» con capital, constituía un mero supuesto, una premisa admisible en abstracto pero indemostrable para ese período de la historia local.

El tenor limitacionista de las anteriores disposiciones y el contenido profundamente elitista que ellas entrañan adquiere su verdadera magnitud cuando se analiza de qué modo era planteada en los decretos de marras la cuestión del riego y cómo habría de resolverse finalmente dicha cuestión. Hasta entonces el servicio venía siendo cumplimentado en la zona por precarios canales construidos o mantenidos con ayuda estatal. Las deficiencias y la evidente insuficiencia de ambos sistemas demandaba a ojos vista la urgente realización de obras de perfeccionamiento, limpieza y prolongación que permitiesen el riego regular de más tierras; no obstante, tanto la experiencia cuanto los estudios realizados demostraban que únicamente la construcción de embalses en el Neuquén y la habilitación de una red de canales de riego y desagües cualitativamente distintos a los existentes podrían resolver el problema de las inundaciones y el de la utilización racional de los cursos fluviales para irrigación.

De allí entonces la falacia de las argumentaciones contenidas en el decreto de 1907 y en los posteriores. El Estado, autojustificándose en una situación de impotencia financiera que supuestamente le impedía concretar las tareas menores de prolongación y limpieza de los canales existentes o construcción de similares donde no los había, procedía a entregar tierras a precio nominal a determinados 
interesados a condición de que éstos realizasen las obras, a sabiendas unos como el otro que las mismas en caso de concretarse sólo podrían servir de momentáneo paliativo a la situación. Es decir que el Estado obviaba hacerse cargo de obras menores que sólo podían brindar cuanto mucho un riego provisional y privatizaba las últimas tierras fiscales de la región en beneficio de quienes supuestamente harían dichos canales; acto seguido, ese mismo Estado comprometía los fondos de Rentas Generales en la construcción de la costosa infraestructura de riego de que hoy goza la región. Más aún. La inversión estatal comenzó con anterioridad a que resultaran sancionados los decretos de 1910 por los que fueron privatizadas las tierras de la porción oriental de la Colonia Roca.

Es que los casos expuestos ejemplifican, ilustrándolo, un comportamiento característico de los sectores más poderosos de la sociedad argentina en el último siglo. Cuando las condiciones económicas de una situación concreta ofrecen promisorias perspectivas de grandes y fáciles ganancias, el Estado es presentado como carente de recursos, incapaz no sólo por ello sino por una supuesta ineficacia intrínseca, de desarrollar las actividades de que se trate y los capitales privados como poseedores de la iniciativa, la capacidad, la eficiencia y los recursos para ello. Luego cuando al cambiar las circunstancias las perspectivas de pérdidas aparecen como algo cierto para el futuro inmediato, ese mismo Estado es presentado como poseedor de medios y de recursos suficientes («Una obra de esta época — dirá Blasco Ibáñez refiriéndose a la suya- no es considerable para un gobierno que cuenta con toda clase de medios») ${ }^{150}$ para acudir en salvación de los particulares. Y los funcionarios gubernamentales, el Estado en concreto, el Estado que también tiene nombre y apellido, se encargarán de encontrar los argumentos para justificar el socorro estatal $-\mathrm{y}$ los casos presentados parecen demostrar que la imaginación e inventiva de los burócratas no tiene límites cuando lo requiere el interés de los poderosos. Ese auxilio estatal, cualquiera sea la forma que adopte,

150 D.E.R.-D.G.T. y C. Expediente núm. 10891-S-1911, folio 7. 
implicará siempre una privatización de beneficios y una socialización de costos y pérdidas. ${ }^{151}$

En el caso de las obras de riego del Alto Valle del río Negro la socialización habría de concretarse en el modo como finalmente aquéllas fueron pagadas. En efecto; para la construcción de las grandes obras hidráulicas el Estado sancionó en 1909 la ley de Irrigación de acuerdo con cuyas disposiciones contrató con la empresa del Ferrocarril del Sud la excavación del gran canal de riego y, merced a un préstamo que le otorgara la citada compañía, procedió a construir el Dique Contralmirante Cordero y el canal aliviador. A cambio de la obra la empresa británica recibiría Bonos de Irrigación emitidos por el Estado argentino que devengarían un interés del $5 \%$ anual y cuyo servicio se haría con el producto líquido del canon de riego o, en su defecto, con las rentas generales de la nación. El gobierno administraría las obras una vez concluidas y cobraría a los beneficiarios un canon de riego lo suficientemente elevado como para permitirle cubrir los gastos de explotación del servicio de riego además de los intereses y el capital adecuado.

Por otro lado la ley establecía que el monto del canon de riego debía ser notificado con antelación a los propietarios para que quienes no estuviesen conformes entregasen sus tierras al precio de tasación anterior al de la ejecución de las obras. El sentido de la disposición era evitar que aquéllas permaneciesen improductivas. Así lo declamaba Ramos Mejía, al inaugurar las obras del dique:

«Preparada la parte de la tarea que corresponde al Gobierno queda librada a los propietarios la realización del vasto pensamiento; no sea que corra el agua fecunda por campos sin surcos, volviendo estéril al río de que salió. La distribución de la tierra que en el cultivo intensivo requiere importante capital para reboscar, nivelar, roturar y sembrar, debe ser lo primero que preocupe con toda inayor razón cuanto que resultará ruinoso para los terratenien. tes el pago de agua en terrenos baldios, que obligatoriamente tendrán que efectuar, la usen o no; disposición que la ley ha tomado

151 Cfr. Ockier: Propiedad de la tierra.... pág. 35. 
precisamente para evitar la actitud de algún mal inspirado que creyera conveniente especular egoístamente con el sacrificio general). ${ }^{152}$

Sin embargo extensas zonas del valle superior del río Negro - dentro y fuera de la Colonia Roca - tardaron décadas en subdividirse e incluso permanecieron incultas por décadas aunque el sistema de riego había quedado completado hacia mediados de la década de 1920.

Es que, como en tantos casos, las disposiciones de la ley se habían convertido en letra muerta en razón de los fuertes intereses que afectaban. Multas, recargos, suspensión del servicio de riego, ejecución judicial de las deudas en concepto de canon impagado, fueron en la práctica sustituidos por decretos concediendo prórrogas para su pago, reducción del importe y condonación de multas y recargos. En consecuencia, más allá de la letra, la política favoreció en la práctica a grandes propietarios y especuladores, algunos de los cuales subdividieron y vendieron inmediatamente aprovechando la revalorización experimentada por sus tierras gracias a las obras que financiadas por el Estado terminaron por pagarse a través de Rentas Generales a un costo que un autor no vacila en calificar de «fabuloso». ${ }^{153}$

Ante los resultados finales de esta política, la mayor parte de los estudiosos tiende a atribuir a elementos difícilmente ponderables (negligencia, descuido, imprevisión, etc.) lo que no ha sido sino una manifestación más de la utilización del Estado y sus recursos en beneficio de los intereses dominantes. ${ }^{154}$

152 Cit. en Rogind, William: Historia del Ferrocarril del Sud. Buenos Aires, 1937, pág. 453.

153 Rey, Ernesto: Río Neoro, el territorio desde 1910, en: «Historia de Río Negro», General Roca, 1975, pág. 110. Los informes de la Dirección General de Irrigación de las décadas de 1910 y 1920 muestran que el porcentaje de canon de riego efectivamente pagado disminuía por zonas a medida que aumentaba el grado de concentración de propiedad de la tierra. En Colonia Picasa, donde prácticamente sólo existían pequeños campesinos propietarios, el porcentaje era de entre 99 y el $100 \%$; en tanto que en la Colonia Roca, de abierto predominio terrateniente, oscilaba entre el 43 y el $53 \%$.

154 Así por ejemplo dice Rey: «En la concepción y ejecución de las obras de riego la preocupación del Estado se centró en los aspectos técnicos, descuidando 
Nada mejor para sintetizar los propósitos de la ley de Irrigación y sus resultados concretos que las siguientes reflexiones del ingeniero Juan Echarren (hijo), en 1929:

(El objetivo de la ley era [...] que las mismas tierras pagasen las obras construidas en forma cómoda y a largo plazo. El defecto básico de la ley aparentemente correcta está en que el primer propietario de la tierra es quien carga con los beneficios. Efectivamente, el primer propietario ve revalorizarse su tierra a consecuencia de la obra construida en la proporción de uno a diez y a veces de uno a cincuenta en las zonas áridas, subdivide y vende al precio del día sin ningún aporte de su parte al pago de las obras construidas que serán abonadas por los que vienen detrás de él. Queda pues burlada la ley en su fundamento y así las cosas en realidad la ley es un obstáculo a la colonización desde que el verdadero trabajador de la tierra es quien llevará la doble carga de la tierra cara y el pago de las obras que las revalorizaron.

Y es así, señores, que expresando claramente lo que muchos saben pero pocos se atreven a decir, que las tierras del valle del Río Negro tienen una deuda de más de $\$ 500 \mathrm{~m} / \mathrm{n}$ por hectárea por concepto de las obras de riego que las benefician y [el] Gobierno Nacional $[\ldots]$ se ve obligado a rescatar los 'Bonos de Irrigación' echando manos a Rentas Generales [...].

En Río Negro se han gastado más de 30 millones en obras y no se llegan a regar 50 mil hectáreas. Estamos pues, señores, hoy en 600 pesos por hectárea». ${ }^{155}$

\section{Marfa Cristina Ockier}

los económicos y administrativos. Así, a pesar de la gran inversión que demandó la misma, el canon fijado sólo cubría los gastos de funcionamiento. Ese descuido también se maniflesta en el hecho de que las tierras regadas a tal costo, fueron a parar en gran medida a manos de especuladores $y$ oportunistas que vieron sextuplicar del día a la noche el valor de sus tierras: de 50 pesos a trescientos (1915) 》.

155 Echarren, Juan (h.): Conferencia en Estación Algarrobo el 21 de julio de 1929 sobre el riego a las tierras del Partido de Villarino. «Revista del Ferrocarril del Sud», Año V, núm. 51, Buenos Aires, septiembre de 1929, págs. 87 y 90. 